
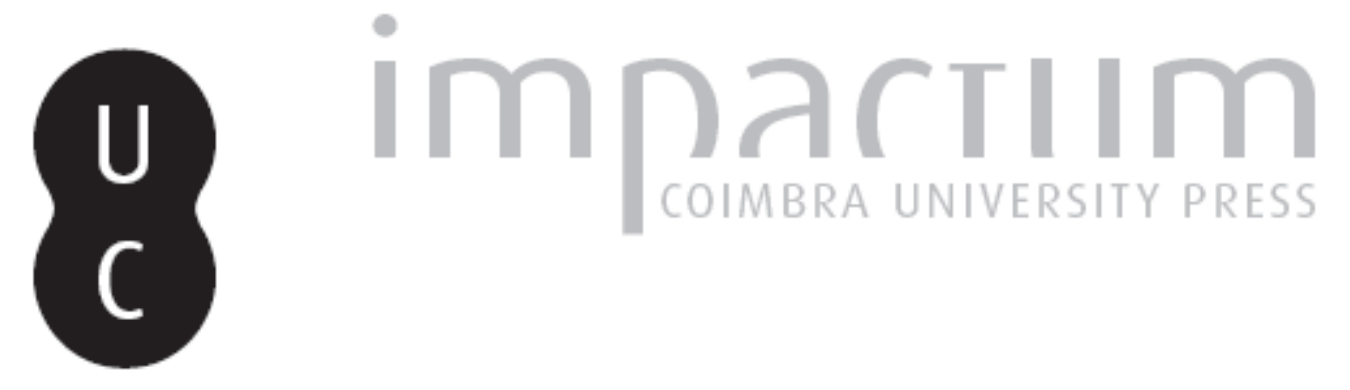

\title{
Necrópoles no territorium de Tongobriga
}

\author{
Autor(es): $\quad$ Dias, Lino A. Tavares
}

Publicado por: Imprensa da Universidade de Coimbra

URL persistente:

URI:http://hdl.handle.net/10316.2/45479

DOI:

DOI:https://dx.doi.org/10.14195/1647-8657_32_33_5

Accessed : $\quad$ 26-Apr-2023 13:03:30

A navegação consulta e descarregamento dos títulos inseridos nas Bibliotecas Digitais UC Digitalis, UC Pombalina e UC Impactum, pressupõem a aceitação plena e sem reservas dos Termos e Condições de Uso destas Bibliotecas Digitais, disponíveis em https://digitalis.uc.pt/pt-pt/termos.

Conforme exposto nos referidos Termos e Condições de Uso, o descarregamento de títulos de acesso restrito requer uma licença válida de autorização devendo o utilizador aceder ao(s) documento(s) a partir de um endereço de IP da instituição detentora da supramencionada licença.

Ao utilizador é apenas permitido o descarregamento para uso pessoal, pelo que o emprego do(s) título(s) descarregado(s) para outro fim, designadamente comercial, carece de autorização do respetivo autor ou editor da obra.

Na medida em que todas as obras da UC Digitalis se encontram protegidas pelo Código do Direito de Autor e Direitos Conexos e demais legislação aplicável, toda a cópia, parcial ou total, deste documento, nos casos em que é legalmente admitida, deverá conter ou fazer-se acompanhar por este aviso.

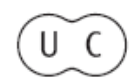




\section{UNIVERSIDADE DE COIMBRA \\ FACULDADE DE LETRAS}

\section{CONIMBRIGA}

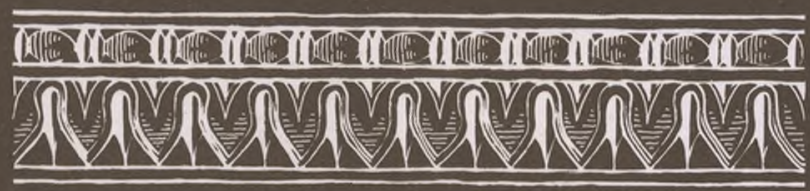

VOLUMES XXXII-XXXIII-1993/94 
Lino A. TAVAREs Dias

Técnico Superior da Direcção Regional do Norte do IPPAR

NECROPOLES NO TERRITORIUM DE TONGOBRIGA

«Conimbriga» XXXII-XXXIII (1993-1994), p. 107-136

RESUMO: O autor procede a um inventário das necrópoles romanas conhecidas na área de Tongobriga (Freixo, Marco de Canaveses). Descreve depois, em pormenor, as duas necrópoles de Valbeirô e Tongobriga de cuja escavação se encarregou e apresenta, sepultura por sepultura, o espólio recolhido.

RÉSUMÉ: L'auteur présente un inventaire des nécropoles d'époque romaine dans la région de Tongobriga (Marco de Canaveses). Les deux nécropoles d'incinération de Valbeirô et Tongobriga, dont il a dirigé les fouilles, sont présentées en détail, avec description du mobilier funéraire (céramique commune et monnaies), tombe par tombe. 
(Página deixada propositadamente em branco) 


\section{NECROPOLES NO TERRITORIUM DE TONGOBRIGA}

Em 1956, o Prof. Bairrão Oleiro publica um trabalho na revista Humanitas (!) em que noticia o achado de uma necrópole em Vila Meã, Concelho de Amarante. O achado ter-se-ia dado quando procediam a desaterros para construção de um bairro. Era certamente a necrópole da villa romana que ali existira. Embora intitulemos este trabalho como "Necrópoles no territorium de Tongobriga", alargamos a observação à margem esquerda do rio Douro, já em terras da Lusitânia, na medida em que as necrópoles ali conhecidas permitem desenvolver algumas comparações pertinentes. Neste território em que a villa e necrópole de Vila Meã se integravam, identificámos 13 necrópoles (Estampa I):

13.01.225 Porto, Amarante, Madalena

1 ATAÚdES (Marancinho)

29TNF785692; $203 \mathrm{~m}$

Necrópole de incineração aberta no afloramento granítico.

Cerâmica comum, recolhida em 1987, dos grupos 3A, 4, 5D, 10, 11 A, aponta para cronologia ampla, dos sécs. II e III ( $\left.{ }^{2}\right)$.

Este sítio era servido pela estrada romana que ligava o rio Tâmega à serra do Marão.

Fortes, 1908, 225; MARQues, 1988, 135-53.

13.01.195 Porto, Amarante, Lomba

\section{SÍTIO DOS PRAZOS, LUGAR DA QUEBRADA}

29TNF786674; $294 \mathrm{~m}$

Necrópole de incineração aberta no afloramento granítico.

(0 Oleiro, J. M. Bairrão (1955-6) Arqueologia, Humanitas, 4-5, Coimbra, 274-84

( $\left.{ }^{2}\right) \mathrm{Na}$ descrição da cerâmica comum seguimos a metodologia apresentada em 1993 no Io Congresso de Arqueologia Peninsular (DIAs, 1995, 325-40). 
Fortes,1908, 252-262; Vasconcelos, 1913, 373; Palazon, 1986, 259; Alarcão, 1988, 24.

13.01.292 Porto, Amarante, Salvador

\section{LOUREDO DAS ALMAS}

29TNF765655;300m

Necrópole de incineração aberta no afloramento granítico.

MARQUES, 1990

\subsubsection{Porto, Penafiel, Croca \\ 4 CROCA}

29TNF633643; 437m

Aldeia ou vicus e necrópole com sepulturas cavadas no afloramento granítico.

$\mathrm{O}$ povoado e a necrópole estavam num ponto saliente na paisagem. No sopé, estende-se, de Sudoeste para Nordeste, uma planície (vale de Croca) rica em água, terras de boa capacidade agrícola. A divisão de propriedade poderia ser semelhante à que existe hoje, segundo eixos ortogonais com a predominância Sudoeste/Nordeste.

Esta zona era servida pela estrada romana que atravessava o vale, ligando a que provinha de Meinedo e seguia pela margem direita do Tâmega, com a que seguia para a ponte de Canaveses em direcção a Tongobriga.

\subsubsection{Porto, Amarante, Vila Caiz}

\section{VILARINHO}

29TNF735649; $150 \mathrm{~m}$

Habitat romano (Villa ?) e necrópole (sécs. III/IV )

Vilarinho é um espaço agradável junto ao rio Tâmega, espraiando-se pelos terrenos com muita água e boa capacidade agrícola até à cota dos $150 \mathrm{~m}$, abrigado pela protecção natural que é o socalco vincado pelos 200m. Era certamente habitado por uma população que se dedicava à agricultura, sem descurar os recursos que o rio Tâmega lhes dava.

Os vestígios arqueológicos foram recolhidos aquando da terraplagem para construção da estação ferroviária de Vila Caiz, inaugurada em 1909. Foram registados vestígios de uma casa com escadas em pedra, tegulae, imbrices, sigillata hispânica do séc. III/IV d.C. Um caminho, que ligava a margem do rio a esta casa, passava junto da necrópole (cujo espólio foi recolhido parcialmente por José de Pinho) e seguia por Retorta e Carreira Chã. As sepulturas eram de incineração, de tipo semelhante às de Croca (Penafiel), caixas abertas no granito degradado, sem revestimento.

Observando-se o sítio, podemos pôr a hipótese de estarmos perante uma estrutura de villa ou de um povoado. Os vestígios arqueológicos foram recolhidos num ponto que morfologicamente se salienta naquele espaço, situado na dobra entre os terrenos mais secos e os que têm abundância de água e grande capacidade agrícola.

As características da zona e a análise do espólio cerâmico, nomeadamente o pintado, permitem dizer que era um espaço onde uma população nos sécs. Ili e IV desenvolvia já a sua actividade agrícola, embora tenhamos que colocar as hipóteses de estarmos perante o fundus ou, como hoje, um conjunto de lavradores que trabalhavam o terreno retalhado. 
FORTES, 1905 - 1908, 477; SOEIRo, 1984, 39; ALARCÃo, 1988, 24.

O espólio foi depositado no Museu de Etnografia do Porto (n.os inv. 7042 e 7182 a 7184). Actualmente encontra-se no Museu D. Diogo de Sousa, Braga. Há também espólio em depósito no Museu Nacional de Arqueologia, n. ${ }^{\circ}$ inv. 1486 (cerâmica comum dos grupos 7A, 10 e 10A).

13.07.096 Porto, Marco de Canaveses, Freixo

29TNF717573; $314 \mathrm{~m}$

\section{TONGOBRIGA}

Cidade, capital de Civitas

A cidade de Tongobriga começou a ser escavada e estudada em Agosto de 1980, num sítio chamado "capela dos mouros", designação dada pela população à pequena parte então visivel das ruínas romanas. Algumas referências bibliográficas apontavam para a existência de vestígios arqueológicos geralmentre conhecidos como "castro".

Actualmente estão classificados como Monumento Nacional cerca de 32 hectares, espaço designado Área Arqueológica de Freixo, onde se podem encontrar ruínas da zona de fruição social, de que se destacam as Termas e o Forum, de zonas habitacionais e de necrópoles.

Tongobriga situava-se junto de vários eixos viários, entre eles a estrada que a partir do séc. I ligava Bracara Augusta a Emérita Augusta.

CIL II S 5554; VASConcelos, 1905, 196; Blázquez, 1962, 136; Vives, 1972, 567; EnCarnação, 1970, 232 e 1975, 185, 195; Tranoy, 1981, 302; Garcia,1991, 357; SOARES-DIAS， 1985; DIAS， 1980; 1980(2)，74-6; 1984，86-90; 1984(2), 77-85; 1985, 106-7; 1986; 1988, 27-30; 1989, 143-6; 1995, 325-40.

13.07.037 Porto, Marco de Canaveses, Avessadas

\section{MÓRIA}

\section{TNF690574; $250 \mathrm{~m}$}

Aldeia e necrópole de incineração aberta no afloramento granítico.

Escavada pelo Arqt. Tasso de Sousa nos anos 50.

Sepulturas com espólio do séc. IV. Cerca de 100 peças cerâmicas associadas a carvões. Indícios de caixas de madeira com cinzas.

Relação visual directa com Tongobriga.

13.02.140 Porto, Baião, Santa Leocádia

\section{BAIRRAL}

29TNF771526; $375 \mathrm{~m}$

Aldeia. Ara a "Iuppiter Optimus Maximus" e necrópole de inumação dos sécs. Ili e IV.

\section{Texto:}

IO VI / O (ptimo) M(aximo )/FL( avius) FR (onto) / EX VOTO LIB (ens)

VASCONCELOS， 1905，379; SEVERo， 1907 - 8; BRANDão， 1960(3)， 78; SOUSA, 1967, 181-96; Vives, 1972, 120; Tranoy, 1981,316; Barroca, 1984, 116-36; AlarCÃo, 1988, 29; GARCIA, 1991, 397

Espólio da necrópole de Santa Leocádia depositado no Museu Nacional de 
Arqueologia, cerâmica comum dos grupos 11 e 12 (n. ${ }^{\circ}$ inv.1438) e a ara no Museu do Seminário Maior do Porto.

13.07.029 Porto, Marco de Canaveses, Ariz

9 EIROZES (Tapada das)

29TNF659528; $200 \mathrm{~m}$

Necrópole de incineração séc. IV.

Espólio em depósito no Museu Nacional de Arqueologia onde deu entrada em Maio de 1902 (cerâmica comum dos grupos 5, 5A, 5D, 6, 9, 10 e 12).

Como acontecia com a necrópole situada em Fraga, a aldeia ou villa a que pertenceu o cemitério de Eirozes era servida pela estrada que seguia ao longo da margem esquerda do Tâmega, ligando Tongobriga ao vicus que existia em Várzea do Douro.

O Comércio do Minho, 19 Abril 1902.

13.07.010 Porto, Marco de Canaveses, Alpendurada

10 FRAG A-Feira Nova

29TNF666521; $293 \mathrm{~m}$

Necrópole de incineração, séc. IV.

Espólio em depósito no Museu Nacional de Arqueologia, onde deu entrada em Maio de 1902 (cerâmica comum dos grupos IA, 3A, 4, 5, 5A, 6, 7A, 9, 10, 10A, 10B, $11 \mathrm{~A}, 12,13$ e 13A).

A aldeia ou villa a que pertenceu este cemitério, que certamente lhe estava próximo, era servida pela estrada que seguia ao longo da margem esquerda do Tâmega, ligando Tongobriga a Várzea do Douro.

O Comércio do Minho, 19 Abril 1902; Vasconcelos, 1913, 372; Alarcão, 1988, 28.

13.02.019 Porto, Baião, Ancede

11 ERMÊLO (Igreja Velha)

29TNF815506; $165 \mathrm{~m}$

Necrópole de que se conhecem quatro sepulturas e tegulae.

O espólio cerâmico dos grupos 9, 11A e 12, que se encontra em depósito no Museu Nacional de Arqueologia, com o n. ${ }^{\circ}$ de inv. 1435, poderá pertencer a esta necrópole.

VASCONCELOS, 1908, 669 - 72; Jornal de Baião, 48, 28 Nov. 1892.

01.06.070 Aveiro, Castelo de Paiva, Sardoura

12 VALBEIRÔ

29TNF851441; 195m

Necrópole de incineração, séc. IV.

18.04.146 Viseu, Cinfães, Souzelo

13 CANCELHÔ

29TNF645465; $240 \mathrm{~m}$

Necrópole de incineração, séc. IV.

SiLVA, 1986, 89-94

Conimbriga, 32-33 (1993-1994), 107-136 
A maioria destas necrópoles são conhecidas a partir de achados esporádicos e quase sempre exumadas sem escavação arqueológica e consequente registo que permita o seu reestudo. Apesar desta condicionante, identificamos 3 tipos de construção: caixas rectangulares cavadas no afloramento granítico; caixas rectangulares construídas com telhas e tijolos; fossas abertas no afloramento granítico, em cujo interior foram construídas caixas rectangulares com pedra.

Neste trabalho procuramos apresentar uma síntese sobre os tipos de enterramento, tomando como referência duas escavações por nós realizadas nas necrópoles de Tongobriga (Freixo, Marco de Canaveses) e de Valbeirô (Castelo de Paiva).

\section{A necrópole de Valbeirô}

A necrópole em Valbeirô (Estampa II) surgiu em condições de emergência idênticas às que levaram o Dr. Bairrão Oleiro a observar o achado de Vila Meã. Quando uma máquina revolvia terras para alargamento de um caminho em terrenos situados na encosta do monte conhecido por Alto de S. Paul( $\left.{ }^{3}\right)$, no lugar de Valbeirô, Freguesia de Sardoura, Concelho de Castelo de Paiva, o manobrador alertou membros da Associação de Defesa do Património de Castelo de Paiva para o aparecimento de caixas em xisto sob o piso do antigo caminho, dentro das quais havia muitas peças cerâmicas. Procurando conciliar a construção do novo caminho e a salvaguarda dos vestígios arqueológicos, a Associação e o Município alertaram os Serviços de Arqueologia da Secretaria de Estado da Cultura.

O sítio onde escavamos a necrópole, na margem esquerda do Douro, já em território da Lusitânia, integra-se em plena bacia desse rio, no espaço também marcado pela confluência dos rios Paiva e Tâmega e pela rede de ribeiros que cortam aqueles vales encaixados. Marcado pelo Alto de S. Paul que atinge 350 meo Alto de S. Gens com $328 \mathrm{~m}$, que o apertam a Nordeste, encontramos um vale com cotas entre os $140 \mathrm{~m}$ e os $170 \mathrm{~m}$ que se estende para Sudeste até ao lugar de Portela, atravessado pelo ribeiro do Quintã, também conhecido como ribeiro de Sá, afluente do rio Sardoura. As facilidades que esse vale dava à per-

$\left(^{3}\right) \quad$ A necrópole situava-se à cota de $195 \mathrm{~m}$, Lat. 41 7' 31', Long. 0 7' 31', carta SCE, folha 135, Castelo de Paiva. 
manência e circulação humana, quer caminhando para Sul, quer para a margem esquerda do rio Douro, justificam a sua riqueza arqueológica. Sítios sobranceiros a esse vale como o monte de Crasto, Quinta do Pedregal, foram ocupados desde há muito.

As características e potencialidades dos solos permitiam certamente aplicar as técnicas agrícolas (ROBERT, 1985, 222-228) mais vulgarizadas no mundo romano (FERDIÈRE, 1991, 81-101). A riqueza mineira em chumbo, zinco e prata, hoje concentrada na região de Paiva, entre o Mont'Alto e margem esquerda do rio Douro, se já então conhecida, poderá ter contribuído também para um maior índice de ocupação da região.

Neste "vale de Sá" os campos que não ultrassavavam a cota dos $170 \mathrm{~m}$ eram irrigados directamente pelo ribeiro que o atravessava.

Num espaço com aptidão agrícola, com as parcelas regularmente orientadas ainda hoje $\left({ }^{4}\right)$ no sentido Noroeste-Sudeste, as populações que trabalhavam as terras instalavam certamente as suas casas nos limites dos campos onde as águas límpidas brotavam da encosta. É pois natural que viessem enterrar os seus mortos já em terrenos de floresta, próximos, mas um pouco mais elevados.

Esta riqueza do solo associada a espaços harmoniosos e agradáveis, protegidos de ventos, com abundância de água, propiciariam bons rendimentos agrícolas, o que poderá justificar a construção de casas romanas com mosaicos (ALARCÃo, 1988, 45) que registamos na região.

Em Valbeirô a primeira intervenção fez-se em 1981. Outras escavações foram posteriormente realizadas já sem o carácter de emergência porque o sítio foi entretanto salvaguardado.

Neste caminho rural que liga o lugar de Casais ao Alto de Fontela, não se notava nenhuma diferença entre a terra das bermas e a do caminho.

Segundo a informação de residentes, próximo do local do achado, antes da escavação arqueológica, tinham sido destruídas cerca de 30 caixas em xisto, com cerca de 0,60/0,70 m de lado, 0,40 m de profundidade, todas com materiais cerâmicos, enterradas a cerca de $0,30 \mathrm{~m}$ abaixo do solo.

Terreno com pinheiros, entre os quais crescia o mato, era coberto por uma camada superficial de terras compactas, duras, enraizadas

(4) A observação comparativa de fotografia aérea feita em 1947 com a de voos recentes confirma a orientação dominante das parcelas agrícolas. 
numa espessura de cerca de 0,20 m. Sob isto uma camada de terras ainda mais endurecidas, algo irregular nos seus $0,30 \mathrm{~m}$ de espessura e de muito difícil escavação. Sob esta camada, granito alterado muito duro apesar de afectado pela humidade da encosta.

Foi neste granito alterado que os "coveiros" de então abriram os buracos rectangulares que depois forravam com placas de xisto.

A escavação permitiu estudar sete sepulturas que não tinham sido afectadas pelos aterros da estrada. Para facilitar o estudo e a apresentação foram numeradas de 1 a 7 , de acordo com a ordem por que foram encontradas. Em todas foi seguida a mesma metodologia e que consistiu na escavação sectorizada segundo dois cortes perpendiculares ao eixo maior e, simultaneamente, seguindo planos horizontais sucessivos. Na sepultura 3, atendendo ao seu bom estado de conservação, foram feitos cortes nos terrenos exteriores adjacentes que permitiram obter estratigrafía (Estampa IV).

\section{SEPULTURA 1}

Depois de escavar a camada superficial e a camada saibrosa, à profundidade de $0,52 \mathrm{~m}$ em relação ao nível do solo, observou-se uma laje quebrada e abatida na zona central. Era a tampa da sepultura afectada pelo peso das raízes dos pinheiros. Apesar disto, o interior da sepultura estava intacto e parcialmente preenchido com terras negras, homogéneas, pouco compactas.

As características da sepultura coincidiam parcialmente com as apontadas pelo manobrador da máquina que tinha desenterrado os primeiros vestígios. Era uma caixa de $0,88 \times 0,6 \mathrm{~m}$, forrada com lajes, e com a profundidade média de $0,40 \mathrm{~m}$.

A escavação do interior permitiu observar 6 peças de cerâmica comum pousadas sobre o fundo nivelado no granito alterado:

1 - Taça - base de assentamento discoidal (50 mm), corpo troncocònico invertido, lábio voltado para o interior; bordo arredondado/ponteagudo, diâmetro boca-104 mm, alt-41 mm. Capacidade-314ml, grupo 10B (Estampa V, 1).

2 - Prato - base de assentamento discoidal $(128 \mathrm{~mm})$, corpo troncocònico invertido, lábio inclinado para o exterior com perfil convexo, bordo oblíquo, diâmetro boca-180mm; alt-48mm. Capacidade-745ml, grupo 3A (Estampa V, 2).

3 - Prato - base de assentamento em aresta $(140 \mathrm{~mm})$, corpo troncocònico invertido, lábio inclinado para o exterior com perfil convexo, bordo arredondado/ponteagudo, diâmetro boca-218mm, alt-67,5mm. Capacidade-2014ml, grupo IA (Estampa V, 3). 
4 - Bilha - base de assentamento em aresta (94 mm); corpo esférico; colo divergente separado do ombro por uma anelura; lábio praticamente vertical e na zona final inclinado para o exterior; bordo circular. Duas asas de fita assimétrica saiem da zona superior do colo e ligam ao ombro, diâmetro boca-62mm, alt-292mm. Capacidade-4749ml, grupo 3A (Estampa V, 4).

5 - Bilha - base de assentamento em aresta $(80 \mathrm{~mm})$, corpo ovoide com aperto na zona inferior, colo convergente (pouco acentuado) separado do ombro por uma anelura. Lábio inclinado para o exterior com perfil côncavo, bordo oblíquo, boca trilobada. Asa de fita assimétrica liga o bordo ao ombro. Alt- $428 \mathrm{~m}$. Capacidade-2110ml, grupo 12 (Estampa V, 5).

6 - Prato - base de assentamento anelar (190mm), corpo troncocònico invertido, lábio voltado para o exterior com ligeiro engrossamento interno, bordo ponteagudo/arredondado, diâmetro da boca-256mm. Alt.-145mm. Capacidade $-1568 \mathrm{ml}$, grupo 11 (Estampa V, 6).

\section{SEPULTURA 2}

Esta sepultura, de morfologia e dimensões semelhantes à n. ${ }^{\circ} 1$, estava muito destruída pelas raízes dos pinheiros. Porque o interior estava pouco preenchido com terra, as placas xistosas das paredes abateram para o interior provocando o esmagamento do espólio. No entanto, foi possível reconstituir:

7 - Jarro - base de assentamento em aresta com ligeiro engrossamento externo $(58 \mathrm{~mm})$, corpo esférico (espessura parede $1,5 \mathrm{~mm}$ ), colo divergente separado do ombro por uma canelura., asa de fita simétrica arranca do ombro. Capacidade-904 ml, grupo 10 (Estampa V, 7).

8 - Potinho - base de assentamento em aresta com ligeiro engrossamento externo (42mm), corpo esférico (espessura parede $2 \mathrm{~mm}$ ), colo convergente, um grafito ocupa parte do ombro. Capacidade-310ml, grupo 10 (Estampa V, 8).

9 - Prato - base de assentamento discoidali 132mm), corpo troncocònico invertido $(6 \mathrm{~mm})$, lábio com perfil recto para o exterior, bordo ponteagudo/arredondado, diâmetro da boca-190mm. Alt.-39mm. Capacidade- $687 \mathrm{ml}$, grupo 11A (Estampa V, 9).

10 - Bilha - base de assentamento em aresta com engrossamento exterior, corpo ovoide com aperto na zona superior $(3 \mathrm{~mm})$, colo divergente, asa de fita assimétrica liga a zona superior do colo ao ombro, lábio vertical e na zona superior inclinado para o exterior com perfil côncavo, bordo circular, diâmetro da boca-40mm. Alt.-224mm, capacidade-1630ml, grupo 5D (Estampa V, 10).

31 (sepultura 2) - Bilha - base de assentamento em aresta (83mm), corpo provavelmente esférico $(3 \mathrm{~mm})$, asa de fita simétrica, grupo IA. O estado fragmentado da peça nao permite analisar mais elementos.

Conimbriga, 32-33 (1993-1994), 107-136 
Nas terras negras que cobriam o fundo da sepultura foram recolhidos dez pregos.

\section{SEPULTURA 3}

Esta sepultura estava intacta.

Foi construída com a mesma técnica das anteriores, paredes em placas xistosas e tampa idêntica. Tinha $0,82 \mathrm{~m}$ de comprimento, 0,55 m de largura e uma profundidade média de $0,35 \mathrm{~m}$. Levantada a tampa, viu-se que a terra, homogénea e escurecida pela cinza, não enchia totalmente a caixa.

Pousadas no fundo recolheram-se sete peças de cerâmica comum:

18 - Prato - base de assentamento em aresta $(12,7 \mathrm{~mm})$, corpo troncocònico invertido, lábio com perfil recto para o exterior, bordo arredondado, diâmetro da boca-166 mm. Alt.-23mm, espessura parede- $7 \mathrm{~mm}$. Capacidade-307 ml, grupo 1 IA (Estampa V, 11)

19 - Potinho - base de assentamento em aresta com ligeiro engrossamento externo $(50 \mathrm{~mm})$, corpo ovoide com aperto na zona superior, colo convergente, lábio inclinado para o exterior com perfil côncavo, espessura parede-2,5 mm, Capacidade-212ml, grupo 10B (Estampa V, 12).

20 - Prato - base de assentamento discoidal (196mm), corpo troncocònico invertido $(7,5 \mathrm{~mm})$, lábio de perfil recto para o exterior, bordo circular (diâmetro da boca-240mm). Alt.-38mm, Capacidade-1143ml, grupo IA (Estampa $\mathrm{V}, 13)$.

21 - Prato - base de assentamento discoidali 160mm), corpo troncocònico invertido, lábio voltado para o interior, bordo circular (diâmetro da boca$-230 \mathrm{~mm}$ ). Alt.-58,5 mm, espessura da parede- $6 \mathrm{~mm}$. Capacidade- $1553 \mathrm{ml}$, grupo 6 (Estampa V, 14).

22 - Bilha - base de assentamento em aresta $(100 \mathrm{~mm})$, corpo ovoide com aperto na zona superior (4 $\mathrm{mm})$, colo divergente, lábio vertical,bordo arredondado (diâmetro boca $380 \mathrm{~mm}$ ). Asa de fita assimétrica que liga a zona superior do colo ao ombro, um apoio para o dedo foi aplicado sobre a asa e ligada ao lábio, alt-182 mm, Capacidade-1220 ml, grupo 6 (Estampa VI, 1).

23 - Bilha - base de assentamento discoidal $(78 \mathrm{~mm})$, corpo esférico (4,5 mm), colo divergente, lábio inclinado para o exterior com perfil côncavo, bordo arredondado, boca trilobada. Asa de fita simétrica que liga o bordo ao ombro. Alt. 184 mm. Capacidade-1200 ml, grupo 12 (Estampa VI, 2).

24 - Potinho - base de assentamento em aresta com ligeiro engrossamento extemo (38mm), corpo ovoide com aperto na zona superior $(2 \mathrm{~mm})$, colo divergente separado do ombro por uma canelura, lábio inclinado para o exterior com perfil côncavo bordo ponteagudo/arredondado, asa de fita simétrica liga o 
bordo à zona superior do colo, diâmetro boca- $42 \mathrm{~mm}$, alt- $115 \mathrm{~mm}$. Capacidade-270 mi, grupo 10B (Estampa VI, 3).

Os dois pratos tinham terra no seu interior e foram esvaziados em laboratorio. Além de terra análoga à do enchimento da sepultura, o prato $n .^{\circ} 21$ continha cinco moedas $\left({ }^{5}\right)$ :

1 - Asse. Roma?, séc I/II d.C. Totalmente desgastada por intensa circulação.

2 - Antoniniano, Galieno. Roma? , 260-268 d.C. Muito desgastada e deteriorada.

3 - Ant. 3 A ou 4 A, F ou K, Cláudio II, Roma, 268-270 d.C. PIAX AVG ou AVGUSTII, RIC VI- 79, 80 ou 81. Muito desgastada.

4 - Ant. 3 F, Cláudio II. Roma, 269-270d.C. IFIDES EXEIRCI. RIC VI-36. Fragmentada e muito desgastada.

5 - Ant. K, Cláudio II. Roma, posterior a 270 d.C. ICONSECRATIOI, altar. RIC VI-261. Fragmentada e muito desgastada.

O desgaste parece-nos natural já que estas moedas datáveis de 98-117 , foram enterradas com outras do séc. IV, as quais também mostram sinais de terem circulado.

\section{SEPULTURA 4}

Muito afectada pelo caminho e por raízes de um grande pinheiro, esta sepultura, cheia de terra misturada com cinza, estava muito degradada. As paredes em placas xistosas tinham abatido para o interior e pisado dois pratos:

16 - Prato - base de assentamento discoidal (134 mm), corpo troncocònico invertido, lábio voltado para o interior com ligeiro engrossamento externo, bordo ponteagudo/arredondado (diâmetro boca-224mm). Alt.58mm, espessura parede-5 mm. Capacidade-1267 ml, grupo IA (Estampa VI, 5).

17 - Prato - base de assentamento discoidali $116 \mathrm{~mm}$ ), corpo troncocònico invertido, lábio inclinado para o exterior com perfil convexo, bordo oblíquo (diâmetro da boca-174mm). Alt.-48,5 mm), espessura da parede-7 $\mathrm{mm}$. Capacidade$-635 \mathrm{ml}$, grupo 1A (Estampa VI, 6).

(5) O estudo das moedas foi feito pelo Dr. Marcelo Mendes Pinto, a quem agradecemos a colaboração neste trabalho. Para a classificação foi utilizado The Roman Imperial Coinage, H. Mattingly, E. A. Sydenham et alli, Londres, 1926.

Para os anversos foram utilizados os códigos, legendas e efígies em RIC, transcrevendo-se apenas as legendas dos reversos. 
40 - Fragmento que não permite determinar a forma completa do potinho, base em aresta $(63 \mathrm{~mm})$, grupo 10B.

Apesar do mau estado da sepultura foi ainda recolhida uma moeda:

6 - Asse, Trajano. Roma?, 98-117 d. C. Totalmente desgastada por intensa circulação.

Alguns fragmentos de um pote (n. $\left.{ }^{\circ} 40\right)$ estavam misturados com as terras no interior da sepultura e o seu mau estado de conservação não nos permite reconstituí-lo.

\section{SEPULTURA 5}

Com dimensões mais reduzidas que as anteriores $(0,52 \times 0,45 \mathrm{~m})$, sem indícios de tampa, não tinha qualquer indício de espólio no interior. Estava completamente cheia de terra igual à exterior envolvente.

\section{SEPULTURA 6}

Com dimensões idênticas à sepultura 5, nesta foi ainda recolhida parte da cobertura feita com várias placas xistosas sobrepostas. Também como a sepultura 5, e ao contrário das restantes, o interior estava completamente cheio de terra e não apresentava o aspecto escurecido pela cinza como as n. $.^{\circ} 1,2,3$ e 4 .

Pousadas sobre a terra do fundo recolhemos:

11 - Taça - base de assentamento anelar $(54 \mathrm{~mm})$, corpo troncocònico invertido (espessura da parede-3,8 $\mathrm{mm}$ ) decorado com cinco linhas pintadas (Palazon, 1986, 224) horizontais paralelas e círculos pintados no espaço entre a segunda e a terceira e entre esta e a quarta, lábio voltado para o interior decorado com linha pintada horizontal, bordo arredondado/ponteagudo, diâmetro da boca$112 \mathrm{~mm}$. Alt.-50mm. Capacidade-314ml, grupo 10A (Estampa VI, 8).

12 - Prato - base de assentamento anelar $(180 \mathrm{~mm})$, corpo troncocònico invertido (espessura da parede-4,5 mm), lábio com perfil recto para o exterior, bordo oblíquo/circular (diâmetro da boca-260mm). Alt.-52,5mm. Capacidade-1596 ml, grupo 1 IA (Estampa VI, 9).

13 - Prato - base de assentamento em aresta $(120 \mathrm{~mm})$, corpo troncocònico invertido (espessura parede- $6 \mathrm{~mm}$ ), lábio voltado para o interior, bordo arredondado (diâmetro da bocal56mm). Alt.39mm. Capacidade-425 ml, grupo 12 (Estampa VI, 7). 
14 - Potinho - base de assentamento em aresta (470mm), corpo esférico, colo convergente (espessura da parede $2 \mathrm{~mm}$ ), lábio pequeno inclinado para $o$ exterior com perfil côncavo, bordo arredondado (diâmetro boca $62 \mathrm{~mm}$ ). Alt.105mm. Capacidade- 120ml, grupo 10B (Estampa VI, 11).

15 - Jarro - base de assentamento em aresta $(56 \mathrm{~mm})$, corpo esférico (espessura parede-1,5mm), colo divergente separado do ombro por uma canelura, lábio voltado para o exterior, bordo ponteagudo(diâmetro boca-62 mm), asa de fita simétrica liga o lábio ao ombro. Alt. $165 \mathrm{~mm}$. Capacidade-1100 ml, grupo 7A (Estampa VI, 12).

\section{SEPULTURA 7}

Muito destruída pelas raízes de um grande eucalipto, não apresentava qualquer indício de caixa. Apesar da degradação recolhemos:

25 - Potinho-base de assentamento em aresta com engrossamento externo e canelura concêntrica $(37 \mathrm{~mm})$, corpo esférico $(1,5 \mathrm{~mm})$, colo convergente separado do ombro por duas caneluras e uma anelura, asa de fita simétrica saía do ombro. Capacidade-310ml, grupo 13A (Estampa VI, 13).

41 - Taça-base de assentamento discoidal $(53 \mathrm{~mm})$, corpo troncocònico invertido $(2,5 \mathrm{~mm})$, lábio inclinado para o exterior com perfil convexo, bordo arredondado/oblíquo (102 mm). Capacidade-170 ml, grupo 3A.

43 - Fragmento de pote, base em aresta $(69 \mathrm{~mm})$, corpo esférico $(2,7 \mathrm{~mm})$. Peça muito queimada e degradada.

Além das 29 peças cerâmicas identificadas em escavação, foram recolhidas 15 em aterro sem contexto estratigráfico:

26 - Taça - base de assentamento anelar $(74 \mathrm{~mm})$, corpo troncocònico invertido $(7 \mathrm{~mm})$, lábio voltado para o exterior, bordo plano (diâmetro da boca$172 \mathrm{~mm}$ ). Alt.-58,5mm. Capacidade- $840 \mathrm{ml}$, grupo 6 (Estampa VI, 10).

27 - Prato - base de assentamento anelar (96 mm), corpo troncocònico invertido $(6 \mathrm{~mm})$, lábio perfil recto para o exterior, bordo oblíquo(diâmetro boca$166 \mathrm{~mm})$. Alt.-37,5mm. Capacidade- $504 \mathrm{ml}$, grupo 5D (Estampa VI, 14).

28 - Prato - base de assentamento em aresta $(150 \mathrm{~mm})$, corpo troncocònico invertido $(7 \mathrm{~mm})$, lábio perfil recto para o exterior, bordo oblíquo (diâmetro boca-200mm). Alt.-45mm. Capacidade-940ml, grupo IA (Estampa 6, 15).

29 - Prato - base de assentamento anelar $(178 \mathrm{~mm})$, corpo troncocònico invertido $(5,6 \mathrm{~mm})$, lábio perfil recto para o exterior, bordo ponteagudo (diâmetro boca-244mm). Alt.-37mm. Capacidade-1100 ml, grupo 11A (Estampa VI, 16).

30 - Jarro - base de assentamento em aresta com engrossamento externo (47 mm), corpo esférico (3 $\mathrm{mm})$, colo divergente, lábio inclinado para o exterior 
com perfil cóncavo, bordo arredondado $(46 \mathrm{~mm})$, asa de fita simétrica liga o bordo ao ombro. Alt.-131mm. Capacidade-463 mi, grupo 10 (Estampa VI, 4).

32 - Prato - base de assentamento discoidal (11Omm), corpo troncocònico invertido $(5 \mathrm{~mm})$, lábio perfil recto para o exterior, bordo moldurado/ponteagudo (diámetro boca-183mm). Alt.-49,5mm. Capacidade- $689 \mathrm{ml}$, grupo $11 \mathrm{~A}$ (Estampa VI, 18).

33 - Prato - base de assentamento discoidali $142 \mathrm{~mm}$ ), corpo troncocònico invertido, lábio perfil recto para o exterior, bordo arredondado/ponteagudo (diámetro boca-188mm). Alt.-30mm. Capacidade-567 mi, grupo 6 (Estampa VI, 19).

34 - Prato - base de assentamento em aresta $(172 \mathrm{~mm})$, corpo troncocònico invertido $(9 \mathrm{~mm})$, lábio inclinado para o exterior com perfil convexo, bordo moldurado/circular $(226 \mathrm{~mm})$, fundo decorado. Alt.-62 mm. Capacidade-1662 mi, grupo 1A (Estampa VI, 20).

35 - Prato - base de assentamento discoidal $(198 \mathrm{~mm})$, corpo tronco -cónico invertido $(6 \mathrm{~mm})$, lábio voltado para o interior, bordo oblíquo $(248 \mathrm{~mm})$, alt-52mm. Capacidade-1672 mi, grupo 3A (Estampa VI, 23).

36 - Taça-base de assentamento anelar $(66 \mathrm{~mm})$, corpo troncocònico invertido $(8 \mathrm{~mm})$, lábio pendente para o exterior, bordo oblíquo/arredondado (144 mm), alt-62mm. Capacidade-418ml, grupo 6 (Estampa VI, 21).

37 - Jarro - base de assentamento em aresta com engrossamento externo e canelura concêntrica $(70 \mathrm{~mm})$, corpo esférico $(2,8 \mathrm{~mm})$, colo divergente separado do ombro por duas caneluras, lábio inclinado para o exterior com perfil concavo, bordo arredondado/circular $(72 \mathrm{~mm})$, asa de fita assimétrica que liga o ombro ao bordo. Alt.-232mm, grupo 1A.

38 - Potinho - base de assentamento em aresta $(52 \mathrm{~mm})$, corpo ovoide com aperto na zona superior $(4 \mathrm{~mm})$, colo convergente. Capacidade-268 mi, grupo 10B (Estampa VI, 22).

39 - Tijela - base de assentamento em aresta $(83 \mathrm{~mm})$, corpo troncocònico invertido $(5,5 \mathrm{~mm})$, lábio inclinado para o exterior com perfil convexo, bordo arredondado/oblíquo(200mm). Alt.-90mm. Capacidade-1780 mi, grupo 5D.

42 - Fragmento que não permite determinar a forma completa do jarro/ /bilha, base discoidal com engrossamento externo $(45 \mathrm{~mm})$, grupo 6 .

44 - Jarro - base de assentamento em aresta com engrossamento externo $(77 \mathrm{~mm})$, corpo esférico $(46 \mathrm{~mm})$, lábio inclinado para o exterior com perfil côncavo, bordo arredondado, grupo 10 .

\section{A necrópole de Tongobriga}

A necrópole romana em Tongobriga (Estampa III) situava-se junto da estrada, a sul da cidade.

No final do século passado foram encontradas sepulturas "reves- 
tidas interiormente com pedaços de tégulas e que tinham tigelas dentro das quais havia ossos".

Foi, então, recolhida cerâmica e vidro, embora muita coisa fosse destruída (VASCONCELOS 1899-1900,32).

Outros textos (VASCONCELOS 1900, 32) informam que:

"Há uns tempos (1897) appareceram no Freixo, em uma surriba, vários objectos de louça e vidro. Fui lá logo; mas perdi o meu tempo. Um objecto de barro cozido, que descreveram de modo que faz suppor que se trata de um galheteiro, ou cousa parecida, tinham-no dado para o Porto; outros objectos, a que chamavam tijellas e que continham ossos, quebraram-nos, na fórma do costume, e enterraram tudo na sorriba; um copo de vidro, que estava ao pé de uma das taes tijellas, partiu-se casualmente, e d'este conservo uns pequeninos cacos que restavam. Todos estes objectos estavam dentro de sepulturas de fórma circular, de pequeno diâmetro, abertas no solo, a pequena profundidade. Ha annos, a uns 30 ou 40 metros arredados d'ali, vi eu uma outra sepultura do mesmo género, que estava revestida interiormente de grandes pedaços de tegulas, e continha uma linda e variada mobília funerária, que remetti para o Museu de Guimarães".

Também no Museu Nacional de Arqueologia, na Sociedade Martins Sarmento e no Museu Municipal de Gaia há espólio da necrópole de Tongobriga.

As escavações que realizámos permitiram identificar sepulturas intactas, abertas no afloramento granítico, orientadas paralelamente à estrada romana que a atravessava.

Com a escavação, confirmamos que o caminho municipal cortou sepulturas, destruindo totalmente algumas e parcialmente outras, como aconteceu nas sepulturas n $.^{\circ} 1,2$ e 10 .

Observamos dois tipos de construção:

No tipo 1, o mais antigo, aproveitando muitas vezes as diáclases, escavavam no granito buracos com comprimento entre $1,50 \mathrm{~m}$ e $2,70 \mathrm{~m}$ e cerca de $0,90 \mathrm{~m}$ de largura, variando a profundidade entre $0,45 \mathrm{~m}$ e $0,75 \mathrm{~m}$. Apesar da dimensão das sepulturas, as peças eram colocadas muito próximas, num dos topos. Era deitada alguma terra que cobria as peças. A sepultura era fechada com pedaços de granito, provavelmente aproveitados entre os que sobravam aquando da abertura do buraco. Este estilo de tampa muito fragmentada, fechou algumas das sepulturas que escavámos;

No tipo 2, para fazerem o enterramento, abriam fossas na terra até encontrarem o afloramento granítico, onde pousavam as peças. São enterramentos posteriores aos que utilizaram o primeiro tipo de sepultura.

Detectámos também enterramentos do tipo 2 e que reaproveitavam 
parte das sepulturas de tipo 1. Nestes casos pousaram as oferendas sobre o "empedrado" que servia de tampa às sepulturas anteriores, provavelmente confundindo-o com o afloramento granítico.

Esta atitude leva-nos a pensar que decorreu algum tempo entre as duas distintas formas de enterramento, já que a segunda demonstra, manifestamente, menos qualidade.

Observamos que algumas sepulturas foram usadas para nelas ser feita a cremação, caso da sepultura 5, algo similar ao identificado em Augusta Emerita (BRÍAs e GonZALO, 1994, 333) e que pode justificar as grandes dimensões das sepulturas, já que as valas recebiam o corpo inteiro antes da cremação. No entanto, em algumas delas os vestígios de carvão são em quantidade reduzida, pelo que certamente só serviram como depósito após a incineração.

As escavações que realizámos permitiram observar 15 sepulturas, as quais são descritas pela ordem de escavação.

Sepultura 1 - tipo 2. Este enterramento estava praticamente junto à camada superficial e, por tal motivo, parcialmente destruído. Algumas das peças estavam incompletas porque destruídas involuntariamente pelo lavrador aquando do corte do mato.

Espólio:

12364 - Pote - base de assentamento em aresta $(72 \mathrm{~mm})$, corpo esférico. Capacidade 1700ml, grupo 10 (Estampa VIII, 2).

49213 - Jarro - base de assentamento discoidal $(81 \mathrm{~mm})$, corpo esférico, colo divergente, lábio voltado para o exterior com perfil recto, bordo arredondado, (diâmetro boca $62 \mathrm{~mm}$ ) Asa de fita simétrica que liga o bordo ao ombro. Alt. $181 \mathrm{~mm}$. Capacidade 1320ml. grupo IA (Estampa VII, 1).

49202 - Prato - base de assentamento discoidal $(135 \mathrm{~mm})$, corpo troncocónico invertido, lábio voltado para o interior com perfil recto, bordo arredondado (diâmetro boca 202mm). Alt. 36mm. Capacidade 730ml, grupo 4 (Estampa VII, 3).

Sepultura 2 - tipo 2. Enterramento idêntico ao da sepultura 1. Espólio:

12363 - Jarro - base de assentamento em aresta (44mm), corpo esférico, colo divergente, lábio voltado para o exterior com perfil côncavo, bordo arredondado (diâmetro boca $40 \mathrm{~mm}$ ), asa de fita que liga o bordo ao ombro. Alt. 154mm. Capacidade 825ml, grupo 10B (Estampa VII, 4).

12365 - Prato - base de assentamento discoidal $(105 \mathrm{~mm})$, corpo troncocónico invertido, lábio voltado para o interior, bordo arredondado (diâmetro boca $146 \mathrm{~mm}$ ). Alt. $38 \mathrm{~mm}$. Capacidade 440ml, grupo IA (Estampa VII, 6). 
12366 - Bilha? - base de assentamento discoidal (116mm), corpo esférico?. Capcidade $1440 \mathrm{ml}$, grupo 4 (Estampa VII, 7).

35153 - Potinho - base de assentamento em aresta $(39 \mathrm{~mm})$, corpo esférico, lábio voltado para o exterior com perfil côncavo, bordo arredondado (diâmetro boca $42 \mathrm{~mm}$ ). Alt. $98 \mathrm{~mm}$. Capacidade $195 \mathrm{ml}$, grupo 5D (Estampa VII, 5).

Sepultura 3 - tipo 1. Enterramento feito através de um buraco, aberto no granito, com $1,95 \mathrm{~m}$ de comprimento, $0,45 \mathrm{~m}$ de largura e $0,60 \mathrm{~m}$ de profundidade.

Estrato 1 - Superficial, camada com 0,25 m de espessura que cobre todo o afloramento, terras castanhas escuras com algumas pedras e raizame.

Estrato 2 - Terras castanhas claras com pedras pequenas e um pouco compacta.

Estrato 3 - Terras castanhas claras, finas

Espólio:

78650 - base de assentamento em aresta $(52 \mathrm{~mm})$, grupo 10B (Estampa VII, 8).

78651 - Prato - base de assentamento em aresta $(132 \mathrm{~mm})$, corpo troncocónico invertido, lábio voltado para o interior com perfil inclinado para o interior, bordo arredondado, (diâmetro boca $172 \mathrm{~mm}$ ). Alt.47mm. Capacidade $764 \mathrm{ml}$ Grupo 5D (Estampa VII, 12).

78652 - Potinho - base de assentamento em aresta com ligeiro engrossamento externo (36mm), corpo ovoide com ligeiro aperto na zona superior, colo divergente, lábio voltado para o exterior com perfil côncavo, bordo arredondado, (diâmetro boca 50mm). Alt.11Omm. Capacidade 180ml, Grupo 7A (Estampa VII, 11).

78653 - Jarro - base de assentamento em aresta com ligeiro engrossamento externo $(46 \mathrm{~mm})$, corpo esférico, colo divergente, lábio voltado para o exterior com perfil côncavo, bordo arredondado (diâmetro boca $56 \mathrm{~mm}$ ). Asa de fita simétrica que liga o bordo ao ombro. Alt. $159 \mathrm{~mm}$. Capacidade $630 \mathrm{ml}$ Grupo 7 (Estampa VII, 10).

78654 - Bilha - trilobada. Peça para restauro, grupo 1A

78655 - Bilha - base de assentamento em aresta com ligeiro engrossamento externo $(56 \mathrm{~mm})$, corpo esférico, colo divergente, lábio voltado para o exterior com perfil côncavo, bordo arredondado, (diâmetro boca $41 \mathrm{~mm}$ ). Asa de fita assimétrica que liga a zona superior do colo ao ombro. Alt. $170 \mathrm{~mm}$. Capacidade $700 \mathrm{ml}$, Grupo 3A (Estampa VII, 9).

Sepultura 4 - tipo 1. Enterramento feito através de um buraco aberto no granito, com $2,55 \mathrm{~m}$ de comprimento, $1,00 \mathrm{~m}$ de largura e $0,60 \mathrm{~m}$ de profundidade.

Estrato 1 - Superficial, camada com $0,30 \mathrm{~m}$ de espessura, que 
cobre todo o afloramento, terras castanhas escuras, com algumas pedras e raizame.

Estrato 2 - Pedras provavelmente da abertura do buraco e que agora servem de tampa à sepultura.

Estrato 3 - Camada de terras castanhas claras, misturadas com muitas pedras pequenas.

Espólio:

78656 - Bilha - base de assentamento discoidal $(63 \mathrm{~mm})$, corpo ovoide com aperto na zona inferior, colo convergente. Capacidade $1150 \mathrm{ml}$, Grupo 4 (Estampa VII, 15).

78657 - Potinho - base de assentamento em aresta $(36 \mathrm{~mm})$, corpo ovoide com aperto na zona superior, colo divergente, lábio voltado para o exterior com perfil côncavo, bordo arredondado (diâmetro boca $52 \mathrm{~mm}$ ). Alt. $105 \mathrm{~mm}$. Capacidade $180 \mathrm{ml}$, grupo 5D (Estampa VII, 13).

78658 - Jarro - base de assentamento em aresta $(56 \mathrm{~mm})$, corpo esférico, colo divergente, lábio voltado para o exterior com perfil côncavo, bordo plano (diâmetro boca $64 \mathrm{~mm}$ ). Asa de fita simétrica que liga o bordo ao ombro. Alt. $162 \mathrm{~mm}$. Capacidade $625 \mathrm{ml}$, Grupo 10B (Estampa VII, 14).

78659- Bilha - base de assentamento em aresta com ligeiro engrossamento externo (45 mm), corpo ovoide, colo divergente, lábio voltado para o exterior com perfil recto, bordo arredondado (diâmetro boca $29 \mathrm{~mm}$ ). Asa de fita simétrica que liga a zona superior do colo ao ombro. Alt. $149 \mathrm{~mm}$. Capacidade $385 \mathrm{ml}$, Grupo 10B (Estampa VII, 18).

78660 - Prato - base de assentamento em aresta com canelura concêntria (134mm), corpo troncocònico invertido, lábio voltado para o interior com perfil recto, bordo arredondado (diâmetro boca $178 \mathrm{~mm}$ ). Alt.48mm. Capacidade 965 ml, Grupo 3A (Estampa VII, 16).

Sepultura 5 - tipo 1. Enterramento feito através de um buraco aberto no granito, com $1,55 \mathrm{~m}$ de comprimento, $0,80 \mathrm{~m}$ de largura e $0,43 \mathrm{~m}$ de profundidade.

Estrato 1 - Superficial, camada com $0,25 \mathrm{~m}$ de espessura, que cobre todo o afloramento, terras castanhas escuras, com algumas pedras e raizame.

Estrato 2 - Terras negras, cinzas, carvões e algumas pedras pequenas. Espólio:

78667 - Pote - base de assentamento em aresta $(70 \mathrm{~mm})$, corpo ovoide com aperto na zona inferior, sem colo, lábio voltado para o exterior com perfil recto, bordo arredondado (diâmetro boca $158 \mathrm{~mm}$ ). Alt. $151 \mathrm{~mm}$. Capacidade $1200 \mathrm{ml}$. Grupo 3A (Estampa VIII, 3).

Este pote servia de urna funerária que continha fragmentos de ossos humanos, parcialmente carbonizados. 
Estrato 3 - Terras castanhas claras, finas, misturadas com algumas pedras.

Espólio:

78661 - Prato - base de assentamento discoidal $(94 \mathrm{~mm})$, corpo troncoconico invertido, lábio voltado para o interior com perfil inclinado para o interior, bordo arredondado, (diâmetro boca $148 \mathrm{~mm}$ ). Alt.41 mm. Capacidade 480ml, grupo 3A (Estampa VII, 17).

78662 - Taça - base de assentamento discoidal, com ligeiro engrossamento extemo $(81 \mathrm{~mm})$, corpo troncocònico invertido, lábio voltado para o interior com perfil inclinado para o interior, bordo arredondado (diâmetro boca $187 \mathrm{~mm}$ ). Alt. $58 \mathrm{~mm}$. Capacidade 1165ml, Grupo 3A (Estampa VII, 21).

78663 - Jarro - base de assentamento em aresta $(81 \mathrm{~mm})$, corpo esférico, colo divergente, separado do ombro por uma canelura horizontal, lábio voltado para o exterior com perfil côncavo, bordo arredondado (diâmetro boca $65 \mathrm{~mm}$ ). Asa de fita simétrica que liga o bordo ao ombro. Alt. $159 \mathrm{~mm}$. Capacidade $950 \mathrm{ml}$, Grupo 12 (Estampa VIII, 2).

78664 - Potinho - base de assentamento em aresta com ligeiro engrossamento externo $(41 \mathrm{~mm})$, corpo esférico, colo divergente, lábio voltado para o exterior com perfil côncavo, bordo arredondado (diâmetro boca $69 \mathrm{~mm}$ ), alt. $99 \mathrm{~mm}$. Capacidade $230 \mathrm{ml}$, Grupo 10 (Estampa VII, 20).

78665 - Bilha - base de assentamento em aresta com engrossamento externo $(56 \mathrm{~mm})$, corpo esférico, colo divergente, lábio voltado para o exterior com perfil côncavo, bordo arredondado (diâmetro boca $40 \mathrm{~mm}$ ). Asa de fita assimétrica que liga a zona superior do colo com o ombro. Alt. $175 \mathrm{~mm}$. Capacidade $670 \mathrm{ml}$. Grupo 7A (Estampa Vili, 1).

78666 - Jarro - base de assentamento em aresta com ligeiro engrossamento externo $(45 \mathrm{~mm})$, corpo esférico, colo divergente, separado do ombro por 3 caneluras horizontais, lábio voltado para o exterior com perfil côncavo, bordo arredondado (diâmetro boca $50 \mathrm{~mm}$ ). Asa de fita simétrica que liga o bordo ao ombro. Alt. $136 \mathrm{~mm}$. Capacidade $525 \mathrm{ml}$, grupo 10 (Estampa VII, 19).

Sepultura 6 - tipo 2. Vala aberta até ao afloramento granítico, onde foram colocadas as peças.

Estrato 1 - Superficial, camada com $0,30 \mathrm{~m}$ de espessura, que cobre todo o afloramento, terras castanhas escuras, com algumas pedras e raizame.

Espólio:

78668 - base - grupo 5D

78669 - Taça - base de assentamento em aresta $(73 \mathrm{~mm})$, corpo troncoconico invertido, lábio voltado para o exterior com engrossamento interno, bordo arredondado (diâmetro boca 156). Alt. $62 \mathrm{~mm}$. Capacidade $900 \mathrm{ml}$, grupo 5D (Estampa VIII, 4). 
78670 - Pote - lábio voltado para o exterior com perfil recto, bordo arredondado (diámetro boca), grupo 3

78671 - Taça - base de assentamento anelar com pé desenvolvido $(87 \mathrm{~mm})$, corpo troncocònico invertido, bordo arredondado, grupo 2

78688 - Bilha - colo divergente lábio vertical, bordo plano grupo 5D.

Sepultura 7 - tipo 1. Enterramento feito através de um buraco aberto no granito, com $1,50 \mathrm{~m}$ de comprimento, $0,70 \mathrm{~m}$ de largura $\mathrm{e}$ $0,68 \mathrm{~m}$ de profundidade.

Estrato 1 - Superficial, camada com $0,40 \mathrm{~m}$ de espessura, que cobre todo o afloramento, castanhas escuras, soltas e com algumas pedras.

Estrato 2 - Terras castanhas claras, saibrosas, misturadas com pedras.

Espólio:

Moeda, Nummus, post 330 d.C., muito desgastada, n. ${ }^{\circ} 641,313.91$

78672 - Potinho - base de assentamento em aresta com ligeiro engrossamento externo $(37 \mathrm{~mm})$, corpo ovoide, colo divergente. Capacidade $270 \mathrm{ml}$, grupo 10

78673 - Prato - base de assentamento em aresta $(95 \mathrm{~mm})$, corpo troncocònico invertido, lábio voltado para o interior com perfil recto, bordo arredondado (diâmetro boca $133 \mathrm{~mm}$ ). Alt. $40 \mathrm{~mm}$. Capacidade $470 \mathrm{ml}$, grupo 3A (Estampa VIII, 5).

78674 - Bilha - base de assentamento em aresta com ligeiro engrossamento externo $(79 \mathrm{~mm})$, corpo esférico, colo divergente, lábio voltado para o exterior com perfil côncavo, bordo arredondado (diâmetro boca $42 \mathrm{~mm}$ ). Asa de fita simétrica que liga a zona superior do colo com o ombro. Alt. $221 \mathrm{~mm}$. Capacidade $1500 \mathrm{ml}$, grupo 10 (Estampa VIII, 10).

78675 - Bilha - base de assentamento em aresta $(80 \mathrm{~mm})$, corpo esférico, colo convergente, lábio voltado para o exterior com perfil recto, bordo arredondado, boca trilobada. Asa de fita simétrica que liga o bordo ao ombro. Alt. 209mm. Capacidade $1630 \mathrm{ml}$. Grupo 12 (Estampa VIII, 9).

78676 - Bilha - grupo 5D

78677 - Bilha - grupo 5D

78678 - base de assentamento em aresta com ligeiro engrossamento externo $(53 \mathrm{~mm})$, corpo esférico. Capacidade aprox ${ }^{\mathrm{a}} 700 \mathrm{ml}$, grupo 6 (Estampa VIII, 8).

78679 - Bilha - frag, de bordo e asa de bilha trilobada. Grupo 4

Sepultura 8 - tipo 1. Enterramento feito através de um buraco aberto no granito, com $2,70 \mathrm{~m}$ de comprimento, $1,10 \mathrm{~m}$ de largura $\mathrm{e}$ $0,75 \mathrm{~m}$ de profundidade.

Estrato 1 - Superficial, camada com $0,40 \mathrm{~m}$ de espessura, que cobre todo o afloramento, terras castanhas escuras, soltas, com algumas pedras e raizame. 
Estrato 2 - Terras castanhas claras (saibrosas), misturadas com bastantes pedras pequenas.

Espólio:

78680 - Taça - grupo 10A

78681 - Prato - base de assentamento discoidal (100 mm), corpo troncocónico invertido, lábio voltado para o interior com perfil inclinado para o interior, bordo oblíquo (diâmetro boca $133 \mathrm{~mm}$ ). Alt.33 mm. Capacidade $360 \mathrm{ml}$, grupo 3A (Estampa VIII, 7).

78682 - Potinho - base de assentamento em aresta $(45 \mathrm{~mm})$, corpo esférico, colo divergente, lábio voltado para o exterior com perfil côncavo, bordo arredondado (diâmetro boca $63 \mathrm{~mm}$ ). Alt. $105 \mathrm{~mm}$. Capacidade $215 \mathrm{ml}$. Grupo 10B (Estampa VIII, 13).

78683 - Bilha - grupo 10

78684 - Potinho - grupo 10B

78685 - Bilha - base de assentamento em aresta com engrossamento externo, grupo 7A,

78686 - Prato - grupo 5D

78687 - Jarro - base de assentamento em aresta com engrossamento externo $(67 \mathrm{~mm})$, grupo 10B (Estampa VII, 8).

Sepultura 9 - tipo 1. Enterramento feito através de um buraco aberto no granito, com $1,22 \mathrm{~m}$ de comprimento, $0,78 \mathrm{~m}$ de largura e $0,65 \mathrm{~m}$ de profundidade. Esta sepultura foi cortada pela estrada municipal.

Estrato 1 - Superficial, camada com 0,30 m de espessura, que cobre todo o afloramento, terras castanhas escuras, soltas, com algumas pedras e raizame.

Estrato 2 - Terras de cor castanho claro finas.

Espólio:

78692 - Bilha - base de assentamento em aresta com ligeiro engrossamento externo $(48 \mathrm{~mm})$, corpo ovoide com aperto na zona superior, colo divergente, lábio voltado para o exterior com perfil convexo, bordo arredondado. Asa de fita assimétrica que liga o bordo com o ombro. Alt. $166 \mathrm{~mm}$. Capacidade 590ml, grupo 7A (Estampa IX, 14).

78693 - Prato - base de assentamento discoidal (133 mm), corpo troncocònico invertido, lábio voltado para o interior com perfil recto, bordo circular (diâmetro boca $176 \mathrm{~mm}$ ). Alt.44mm. Capacidade $840 \mathrm{ml}$. Grupo 4 (Estampa VIII, 15).

78694 - Jarro - base de assentamento em aresta $(56 \mathrm{~mm})$, corpo esférico, colo divergente separado do ombro por 2 caneluras horizontais, lábio voltado para o exterior com perfil côncavo, bordo arredondado (diâmetro boca $70 \mathrm{~mm}$ ). Asa de fita simétrica que liga o bordo ao ombro. Alt. $155 \mathrm{~mm}$. Capacidade $905 \mathrm{ml}$, grupo 7A (Estampa VIII, 16). 
78695 - Potinho - base de assentamento em aresta com ligeiro engrossamento extemo $(44 \mathrm{~mm})$, corpo ovòide com ligeiro aperto na zona superior, colo divergente, lábio voltado para o exterior com perfil côncavo, bordo arredondado (diâmetro boca $53 \mathrm{~mm}$ ). Alt.96mm. Capacidade $150 \mathrm{ml}$, gmpo 5D (Estampa IX, 11).

Sepultura 10 - tipo 1. Enterramento feito através de um buraco aberto no granito, com $1,90 \mathrm{~m}$ de comprimento, $0,90 \mathrm{~m}$ de largura e $0,75 \mathrm{~m}$ de profundidade (Estampa IV).

Estrato 1 - Superficial, camada com 0,30 m de espessura, que cobre todo o afloramento, terras castanhas escuras, soltas, com algumas pedras e raizame.

Estrato 2 - Pedras que serviam de tampa à sepultura.

Estrato 3 - Camada de terras castanhas claras, saibrosas.

Espólio:

78696 - Prato - base de assentamento discoidal $(110 \mathrm{~mm})$, corpo troncocònico invertido, lábio voltado para o interior com perfil convexo, bordo arredondado (diâmetro boca $150 \mathrm{~mm}$ ). Alt. $38 \mathrm{~mm}$. Capacidade $580 \mathrm{ml}$, grupo IA (Estampa IX, 4).

78697 - Potinho - base de assentamento em aresta com ligeiro engrossamento externo $(39 \mathrm{~mm})$, corpo esférico, colo divergente, lábio voltado para o exterior com perfil côncavo, bordo arredondado (diâmetro boca $52 \mathrm{~mm}$ ). Alt. $107 \mathrm{~mm}$. Capacidade $220 \mathrm{ml}$, grupo 10B (Estampa IX, 10).

78698 - Jarro - base de assentamento em aresta com ligeiro engrossamento externo $(57 \mathrm{~mm})$, corpo ovoide, colo divergente, separado do ombro por 3 caneluras horizontais, lábio voltado para o exterior com perfil côncavo, bordo arredondado (diâmetro boca $63 \mathrm{~mm}$ ). Asa de fita assimétrica que liga o bordo ao ombro. Alt. 143mm. Capacidade $525 \mathrm{ml}$. Grupo 7A (Estampa VIII, 12).

78699 - Bilha - base de assentamento discoidal $(58 \mathrm{~mm})$, corpo esférico, colo divergente, lábio voltado para o exterior com perfil côncavo, bordo arredondado,boca trilobada. Asa de fita simétrica que liga o bordo ao ombro. Alt. $185 \mathrm{~mm}$. Capacidade $1200 \mathrm{ml}$, grupo 4 (Estampa VIII, 14).

78700 - Bilha - base de assentamento em aresta com ligeiro engrossamento externo $(50 \mathrm{~mm})$, corpo esférico, colo divergente, lábio voltado para o exterior com perfil côncavo, bordo plano (diâmetro boca $43 \mathrm{~mm}$ ). Alt. $192 \mathrm{~mm}$. Capacidade $1000 \mathrm{ml}$. Grupo 10 (Estampa VIII, 11).

Sepultura 11 - tipo 1. Enterramento feito através de um buraco aberto no granito, com $1,85 \mathrm{~m}$ de comprimento, $0,80 \mathrm{~m}$ de largura e $0,65 \mathrm{~m}$ de profundidade.

Estrato 1 - Superficial, camada com $0,20 \mathrm{~m}$ de espessura, que cobre todo o afloramento, terras castanhas escuras, soltas, com algumas pedras e raizame.

Conimbriga, 32-33 (1993-1994), 107-136 
Estrato 2 - Pedras que serviam de tampa à sepultura.

Estrato 3 - Camada de terras castanhas claras, misturadas com algumas pedras pequenas.

Espólio:

Moeda, tipo GLORIAEXERCITUS, 337-340 d.C., n. ${ }^{\circ} 643,313.92$

78702 - Prato - base de assentamento discoidal $(138 \mathrm{~mm})$, corpo troncocónico invertido, bordo arredondado (diâmetro boca 180mm). Alt.ólmm. Capacidade Grupo IA (Estampa VIII, 17).

78703 - Potinho - base de assentamento em aresta com ligeiro engrossamento externo $(46 \mathrm{~mm})$, corpo ovoide com ligeiro aperto na zona superior, colo divergente, lábio voltado para o exterior com perfil côncavo, bordo arredondado (diâmetro boca $52 \mathrm{~mm}$ ). Alt. $103 \mathrm{~mm}$. Capacidade $180 \mathrm{ml}$, grupo 5D (Estampa IX, 2).

78704 - Bilha - base de assentamento em aresta com ligeiro engrossamento externo $(75 \mathrm{~mm})$, corpo esférico, colo divergente, lábio voltado para o exterior com perfil côncavo, bordo arredondado (diâmetro boca $38 \mathrm{~mm}$ ). Asa de fita simétrica que liga a zona superior do colo com o ombro. Alt. $199 \mathrm{~mm}$. Capacidade $1380 \mathrm{ml}$, grupo 9 (Estampa IX, 7).

78713 - Bilha - grupo 1

Sepultura 12 - tipo 1. Enterramento feito através de um buraco aberto no granito, com 2,20 m de comprimento, $1,10 \mathrm{~m}$ de largura $\mathrm{e}$ 0,40m de profundidade.

Estrato 1 - Superficial, camada com 0,23 m de espessura, que cobre todo o afloramento, terras castanhas escuras, soltas, com algumas pedras e raizame.

Estrato 2 - Terras castanhas claras, finas, com algumas pedras pequenas.

Espólio:

Moeda, GLORIA EXERCITUS, Trier, 337-340 d.C., n. ${ }^{\circ} 634,313.92$

Moeda, Constantinus, 347-348 d.C., n. ${ }^{\circ}$ 635, 313.92

Moeda, tipo GLORIA EXERCITUS, 337-340 d.C., n. ${ }^{\circ} 636,313.93$

Moeda, tipo GLORIA EXERCITUS, 337-340 d.C., n. ${ }^{\circ} 637,313.93$

Moeda, tipo GLORIA EXERCITUS, 337-340 d.C., n. ${ }^{\circ} 638,313.92$

Moeda, ilegível, >337 d.C., n. ${ }^{\circ} 639,313.92$

Moeda, GLORIA EXERCITUS, Constantinopla, 337-340 d.C., n. ${ }^{\circ}$ 640, 313.91

78705 - Potinho - base de assentamento em aresta com ligeiro engrossamento externo $(38 \mathrm{~mm})$, corpo ovoide com ligeiro aperto na zona superior, colo divergente, lábio voltado para o exterior com perfil côncavo. Capacidade $310 \mathrm{ml}$, grupo 5D (Estampa IX, 12).

78706 - Bilha - grupo 10

Conimbriga, 32-33 (1993-1994), 107-136 
78707 - Bilha - base de assentamento discoidal (94mm), corpo ovòide com aperto na zona inferior, colo divergente. Arranque de asa de fita simétrica na zona superior do ombro. Capacidade $2300 \mathrm{ml}$, grupo 4 (Estampa IX, 5).

78708 - Jarro - base de assentamento em aresta com ligeiro engrossamento externo $(51 \mathrm{~mm})$, corpo ovoide, colo divergente, separado do ombro por duas caneluras horizontais, lábio voltado para o exterior com perfil côncavo, bordo arredondado. Capacidade 560ml. Grupo 3A (Estampa IX, 9).

Sepultura 13 - tipo 1. Enterramento feito através de um buraco aberto no granito, com $1,50 \mathrm{~m}$ de comprimento, $0,75 \mathrm{~m}$ de largura e $0,60 \mathrm{~m}$ de profundidade.

Estrato 1 - Superficial, camada com $0,35 \mathrm{~m}$ de espessura, que cobre todo o afloramento, terras castanhas escuras, soltas, com algumas pedras.

Estrato 2 - Pedras que serviam de tampa à sepultura.

Estrato 3 - Camada de terras castanhas claras, com algumas pedras pequenas.

Espólio:

Moeda, ilegível, >330 d.C., n. ${ }^{\circ}$ 642, 313.89

78710 - Bilha - base de assentamento discoidal $(90 \mathrm{~mm})$, corpo ovoide com aperto na zona inferior, colo divergente, lábio voltado para o exterior com perfil côncavo, bordo arredondado (diâmetro boca $75 \mathrm{~mm}$ ). Alt. $204 \mathrm{~mm}$. Capacidade $1770 \mathrm{ml}$, grupo 4 (Estampa IX, 6).

78711 - Jarro - base de assentamento em aresta $(56 \mathrm{~mm})$, corpo ovoide, colo divergente, separado do ombro por uma canelura horizontal, lábio voltado para o exterior com perfil côncavo, bordo arredondado. Asa de fita simétrica que liga o bordo ao ombro. Alt. $180 \mathrm{~mm}$. Capacidade $1150 \mathrm{ml}$, grupo 3A (Estampa IX, 8).

78712 - Potinho - base de assentamento em aresta com ligeiro engrossamento externo $(35 \mathrm{~mm})$, corpo esférico, colo divergente, lábio voltado para o exterior com perfil côncavo, bordo arredondado (diâmetro boca $42 \mathrm{~mm}$ ). Alt.87mm. Capacidade $140 \mathrm{ml}$, grupo 3A (Estampa IX, 1).

Sepultura 14 - tipo 2. Pequena vala, sobreposta à sepultura 12 . Usou as lajes que a tapavam para servir de fundo onde pousaram a peça.

Estrato 1 - Superficial, camada com 0,30 m de espessura, que cobre toda a sepultura 12 e afloramento, terras castanhas escuras, soltas, com algumas pedras e raizame

Espólio:

78701 - Jarro - base de assentamento em aresta (67mm), grupo 10B 
Sepultura 15 - tipo 2. Pequena vala, sobreposta à sepultura 14 . Usaram as lajes que tapavam aquela sepultura para servir de fundo onde pousaram a peça.

Estrato 1 - Superficial, camada com $0,35 \mathrm{~m}$ de espessura, que cobre toda a sepultura 14 e afloramento, terras castanhas escuras, soltas, com algumas pedras.

Espólio:

78709 - Pote - grupo 1A (Estampa IX, 3).

\section{Conclusões}

A análise global dos espólios recolhidos em Valbeirô permite concluir que estamos perante uma necrópole homogénea, com sepulturas feitas com lajes, constituindo caixas com tampa. A cerâmica é toda comum romana, de fabricos idênticos, pastas muito semelhantes, formas vulgares.

Apesar da homogeneidade que pode ser vista nestas sepulturas, parece-nos no entanto haver dois tipos de construção. Um constituído pelas sepulturas 1, 2 e 3, um outro pelas 5 e 6 . Estas duas sepulturas foram feitas com menos cuidado e parecem ligeiramente desenquadradas das restantes, embora não seja possível grande discussão, tanto mais que não sabemos o número exacto das que foram destruídas no aterro inicial.

As sepulturas 4 e 7 , porque estavam muito degradadas, são difíceis de incluir em qualquer dos grupos.

Deste conjunto de sepulturas só a 3 e a 4 tinham moedas que ajudam a um enquadramento cronológico. O desgaste das cinco moedas recolhidas na sepultura 3 indiciam um enterramento feito já no séc. IV. Os enterramentos com um número apreciável de moedas parece terem sido mais vulgares no séc. IV $\left.{ }^{6}\right)$. Talvez por questão de moda, o número de moedas é normalmente inferior nos enterramentos anteriores.

Apesar da sepultura 4 só ter fornecido um Asse muito desgastado de Trajano, e isso poder indiciar enterramento cronologicamente ante-

$\left(^{6}\right)$ Esta observação foi uma constante na necrópole de Croca, Penafiel, escavada pelo Serviço Regional de Arqueologia da Zona Norte em 1988 e 1989.

Conimbriga, 32-33 (1993-1994), 107-136 
rior ao da sepultura 3, a semelhança tipològica da cerâmica não nos permite avançar mais, pois são peças com formas e pastas que os oleiros trabalharam do mesmo modo durante muito tempo (Estampa X).

Na década de 30, no lugar de Vales, na proximidade de Portela, foi recolhido espólio de uma necrópole que, apesar das informações que foram publicadas (PINHO, 1947, 52) serem bastante sumárias, permitem ver grandes semelhanças com a de Valbeirô agora estudada.

Também em Setembro de 1927, segundo Ruy de Serpa Pinto (Gonçalves, 1989,472-79), no lugar de Campo da Torre, Freguesia de Sardoura, foram recolhidas peças que pertenciam a uma necrópole. As moedas então recolhidas levaram o autor a datá-la do séc. IV d.C..

Embora só cotejando com os desenhos e descrições que o autor fez de algumas peças cerâmicas, encontramos também semelhanças com as por nós recolhidas na escavação em Valbeirô.

Porque estavam próximas, apesar da separação do rio Douro, recordamos as semelhanças com a descrição que José Leite de Vasconcelos (1913) fez das sepulturas da necrópole de Fraga (Marco de Canaveses) e os materiais recolhidos na escavação ali feita em $1902\left({ }^{7}\right)$, assim como em Eirozes, cujos espólios estão depositados no Museu Nacional de Arqueologia.

Outros casos têm sido registados, como em Cancelhô-Cinfães $\left(^{8}\right)$, reforçando a ideia de que estamos perante um tipo de enterramento muito habitual na região no séc. IV. Em Valbeirô todas as sepulturas tinham várias peças cerâmicas, excepto a 5 que certamente nunca foi utilizada, apesar de também ser possível estarmos perante uma sepultura "imaginária” (PRIEUR, 1986, 17).

Pelos achados registados nesta região da margem esquerda do rio Douro, mesmo que dispersos, como as moedas de Constante e Constâncio II recolhidas no lugar de Sta. Cecília (PINHO, 1947, 54-56), observamos uma grande concentração de elementos que indiciam uma ocupação significativa naquela região nos séc. Ili e IV, sinónimo certamente da estabilidade demográfica que se faria então sentir.

Julgamos poder confirmar que o rito da incineração era ainda o

(7) Notícia da escavação no Jornal O Comércio do Minho,19 Abril de 1902.

$\left(^{8}\right)$ Eduardo Pires de Oliveira, Relatório de ocorrência do Serviço Regional de Arqueologia da Zona Norte,1981; Fernando Seixas, Jornal de Notícias, 9 Junho 1982; Eduardo Jorge Lopes da Silva, Intervenção de Emergência na Sepultura de CancelhôSouzelo, Cinfães, Revista de Ciências Históricas, 1,1986,89-99. 
dominante nesta época (AlARCÃO, 1983:192) nestas zonas da Galecia e da Lusitania, apesar de já ter entrado em desuso noutras zonas do Império (PRIEUR, 1986, 27).

$\mathrm{O}$ mesmo rito podemos encontrar na necrópole de Tongobriga. Aqui, as sepulturas foram abertas no afloramento granítico mas não houve qualquer construção como em Valbeirô.

Em Tongobriga (Estampa $\mathrm{X}$ ) depositavam um número variável de peças cerâmicas, entre uma e oito, e em algumas juntavam moedas. $\mathrm{Na}$ sepultura $n .{ }^{\circ} 7,11$ e 13 colocaram uma moeda, enquanto na n. ${ }^{\circ} 12$ depositaram sete, todas elas apontando cronologia da segunda metade do séc. IV.

$\mathrm{Na}$ necrópole escavada no lugar de Acucanha, Croca, Penafiel, identificamos sepulturas iguais às de Tongobriga. Em todas elas o cerimonial do enterramento após a incineração incluiu a colocação de peças cerâmicas dentro da sepultura, por vezes também moedas. Depois cobriam as peças e as cinzas com alguma terra e fechavam as sepulturas com placas de xisto, no caso de Valbeirô, e com cascalho, no caso de Tongobriga. Alguma terra misturada com o saibro, saído aquando da abertura do buraco, era lançada sobre estas caixas sepulcrais.

Observadas as 13 necrópoles identificadas na região (Estampa I), conclui-se que pode ser-lhes apontada a cronologia genérica de final do séc. III até início do séc. V. Embora sejam contemporâneas, na zona do vale do rio Douro, nas duas margens, as sepulturas eram do tipo "caixa" forradas com pedras, enquanto mais a Norte o enterramento era mais simples, limitado à abertura da vala no afloramento granítico.

A ritualidade, como actualmente continua a acontecer, não era condicionada por divisões administrativas entre a Galecia e a Lusitania ou por condições naturais, como o rio Douro.

\section{BIBLIOGRAFIA CITADA}

AlarCão, Jorge (1983) Portugal Romano, Lisboa (Ia ed. 1973)

- (1988) O Domínio Romano em Portugal, Lisboa

BArroca, M. Jorge (1984) Notas sobre a ocupação Medieval em Baião, Arqueologia, 10, Porto, 116-36

BLázquez, J. M. (1962) Religiones primitivas de Hispania. I. Fuentes literarias y epigráficas, Madrid.

Conimbriga, 32-33 (1993-1994), 107-136 
Brandão, Domingos P. (1959) Ara dedicada a Júpiter de Carvalho de Rei, Douro-Litoral, 9, 4, Porto, 903-13

- (1960) Novas Estelas Funerárias de Várzea do Douro, Revista de Guimarães, 70, 1-2, Guimarães, 185-96

- (1960) 2 Monumento Sepulcral em forma de ara com inscrição latina de Santa Marinha do Zêzere, Revista de Guimarães, 70, 3-4, Guimarães, 485-90

- (1960) 3 Ara dedicada a Júpiter de Santa Leocádia de Baião no Museu do Seminário Maior do Porto, Humanitas, 11-2, Coimbra, 76-9

Brías, J. Molano; Gonzalo, M. Alvarado (1994) La Evolución del Ritual Funerario de Augusta Emérita como Indicador del Cambio Social, Ideologico y Religioso, Actas do $l .{ }^{\circ}$ Congresso de Arqueologia Peninsular, 3, Porto, 321-50

Dias, Lino Tavares (1980) Área Arqueológica do Freixo (Escavaçõesl980), Marco de Canaveses

-(1980)2 Estação Arqueológica Romana de Paleagas-Freixo, Arqueologia, 2, Porto, 74-6

- (1984) Estação Arqueológica de Freixo-Marco de Canaveses, Arqueologia, 9, Porto, 86-90

- (1984) 2 Área Arqueológica de Freixo, Informação Arqueológica, 4, Lisboa, 77-85

- (1985) Área Arqueológica de Freixo, Informação Arqueológica, 5, Lisboa, 106-7

-(1986) Área Arqueológica de Freixo. Guia de visita/Edifício termal romano, Marco de Canaveses

- (1988) Área Arqueológica de Freixo como espaço colectivo. Uma cidade romana. Actas do l. $^{\circ}$ Congresso de Historia Antigua, 3, Santiago de Compostela, 27-30

-(1989) Tongobriga, Os Caminhos Romanos que ali Chegavam, Arqueologia, 19, Porto, $143-6$

- (1995) Cerâmica Comum em Tongobriga, $1 .^{\circ}$ Congresso de Arqueologia Peninsular-Actas VI, Trabalhos de Antropologia e Etnologia, 35(2), Porto, 325-40

EnCARNAÇão, José d' (1970) Lápides a divindades indígenas no Museu de Guimarães, Revista de Guimarães, 80 (3-4), Guimarães, 207-38.

- (1975) Divindades indigenas sob o domínio romano em Portugal, Lisboa

Ferdière, ALAin (1991) Gaulois et Gallo-Romains: Tecniques et Outillage Agricoles, in Pour une Archéologie Agraire, dir. Jean Guillame, Paris,81-101

Filgueiras, J; Marrana, A (1978) Levantamento Arqueológico do Concelho de Castelo de Paiva, Revista de Guimarães, Guimarães

ForTes, JosÉ (1905-08) Casa e Necrópole Lusitano-Romano de Vilarinho (Amarante), Portugália, 2, Porto, All

- (1908) Necrópole de Ataúdes Freguesia de Madalena (Amarante), Portugália, Porto, 225

Garcia, José Manuel (1991) Religiões Antigas de Portugal, Lisboa

GeniÈre, JUlietTe (1990) Les Sociétés Antiques à travers leurs nécropoles, Mélanges de U École Française de Rome, Antiquité, Tome 102-1, Roma, 83-91

Gonçalves, António H. B. (1989) Novos inéditos de Ruy de Serpa Pinto, Boletim Cultural da Póvoa do Varzim, vol XXVI, 2, Póvoa do Varzim 
Guimarães, Oliveira (1901) Catálogo do Museu Arqueológico (da Sociedade Martins Sarmento). Revista de Guimarães, 18(1-2), Jan.-Abr. 1901, 38-72

Marques, J. A. MAIA (1988) Cerâmica da Necrópole Galaico-Romana dos Ataúdes (Madalena-Amarante), Revista de Ciências Históricas, 3, Porto, 135-53

Marques, J. A. M; Silva, M e Amaral, L. (1990) Cerámica da Necrópole Galaico-romana de Louredo das Almas (Salvador-Amarante), Entremuros, 1, Amarante, $15-20$

OleIRo, J. M. BAIRRão (1955-6) Archaeologica, Humanitas, 4-5, Coimbra, 274$-284$

Palazon, J. M. Abascal (1986) La Cerámica Pintada Romana de Tradición Indigena en La Península Ibérica, Centros de Producción, Comercio y Tipologia, Madrid

Pinho, Margarida R. M. (1947) Elementos para a Historia de Castelo de Paiva, Coimbra

Prieur, JeAN (1986) La mort dans Tantiquité romaine, Ouest-France

Robert, JEAN Noel (1985) La Vie à la Campagne dans L'Antiquité Romaine, Paris

SEVERo, Ricardo (1907) Necrópoles Lusitano-Romanas de Inumação de Bairral e de Vila Verde, Portugália, 2, 3, Porto, 417-31

Silva, Armando Coelho F. 1986) A Cultura Castreja no Noroeste Peninsular, Paços de Ferreira

Silva, EduARdo Jorge Lopes (1986) Intervenção de Emergência na sepultura de Cancelhô-Souselo, Cinfães, Revista de Ciências Históricas, I, Porto, 89-94

Soares, Rosa M.; Dias, Lino (1985) Área Arqueológica de Freixo-Contributo Documental $1758-1984$, Porto

SoEIro, Teresa (1984) Apontamentos Sobre a Ocupação Entre Sousa e Tâmega em Época Romana, Boletim Municipal de Cultura, 1, Penafiel, 5-323

SousA, J. J. Rigaud (1967) Novas Observações Sobre a Necrópole do Bairral, Revista de Etnografia, Julho, 9, 1, Porto, 181-96

Tovar, António (1989) Iberische Landeskunde, 3, Baden-Baden

Tranoy, Alain (1981) La Galice Romaine, Recherches sur le Nord-ouest de la Péninsule Ibérique dans VAntiquité, Paris, 393-4

VAsconcelos, João (1908) Materiais para o Inventário Arqueológico do Concelho de Baião, Portugália, 2, Porto, 669-73

VAsconcelos, José Leite (1899-1900) Sepulturas romanas em Marco de Canaveses, O Arqueólogo Português, 5, 1, Lisboa, 32

(1897-1905-1913) Religiões da Lusitânia, 1-2-3, Lisboa (reed. 1981)

Viterbo, Johquim de SANTa Rosa (1983) Elucidário das Palavras, Termos e Frases, Porto

VIVES, José (1972) Inscripciones Latinas de la España Romana, Barcelona.

Conimbriga, 32-33 (1993-1994), 107-136 
EST. I
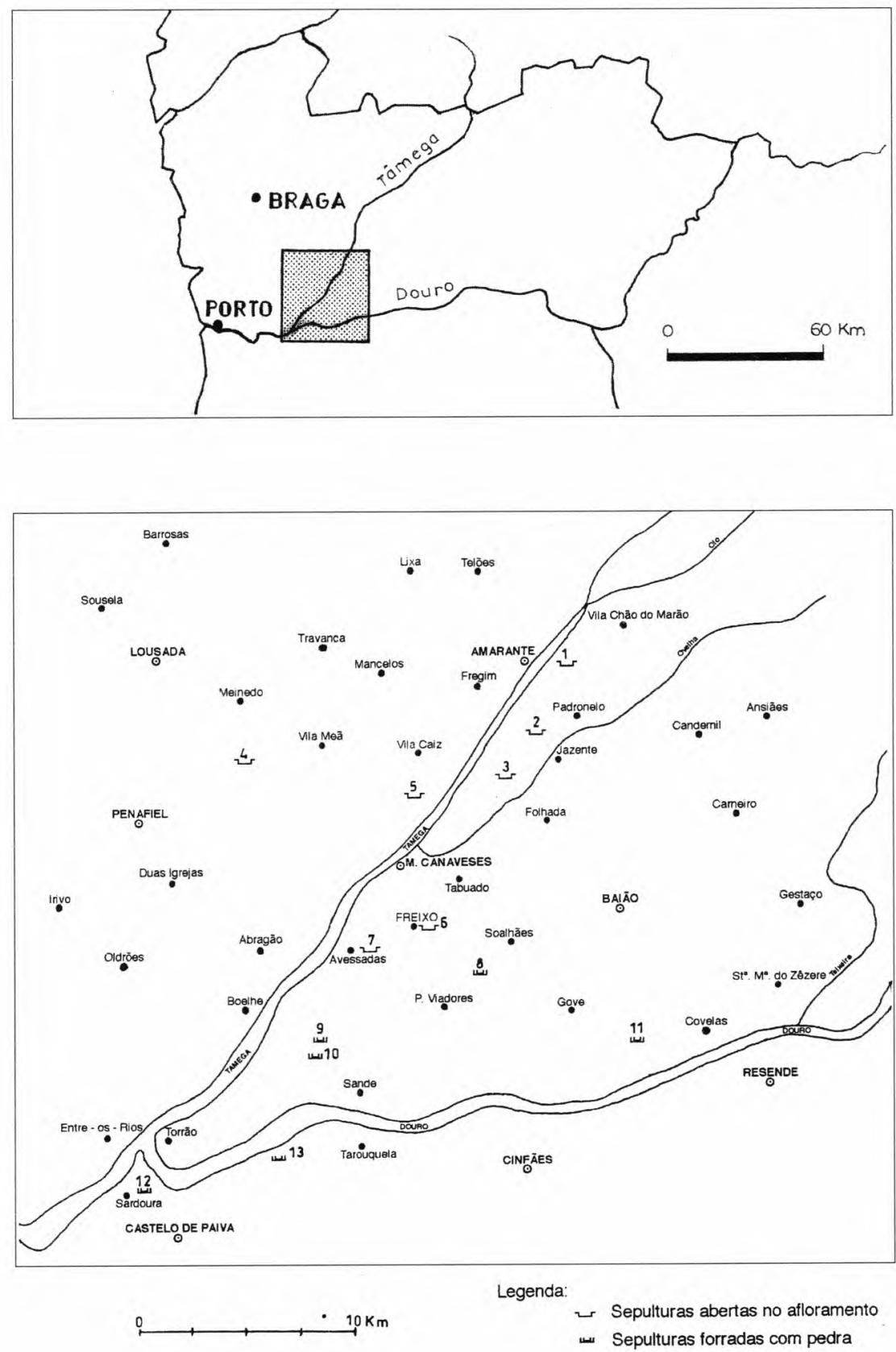
EST. II

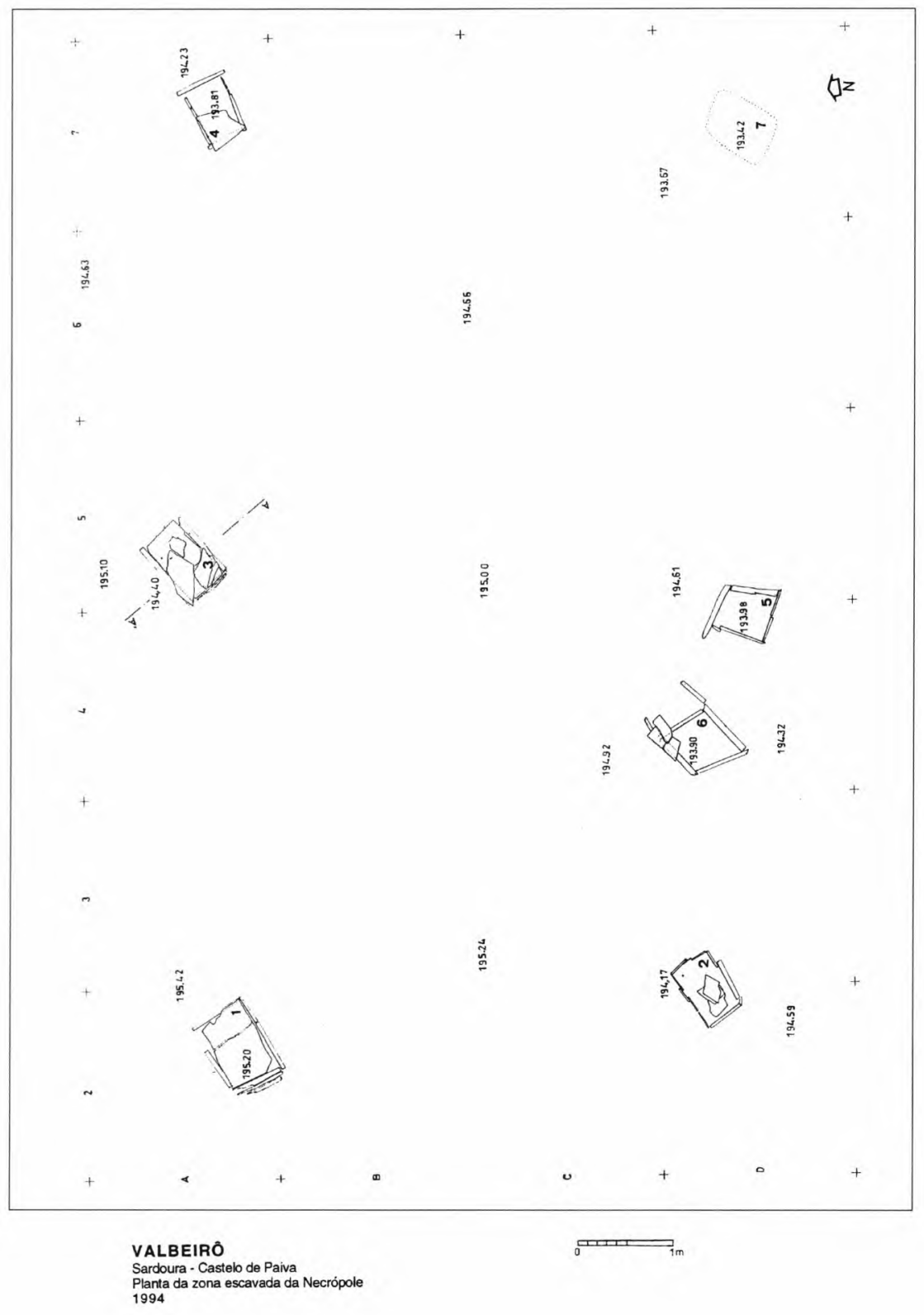


EST. IIA

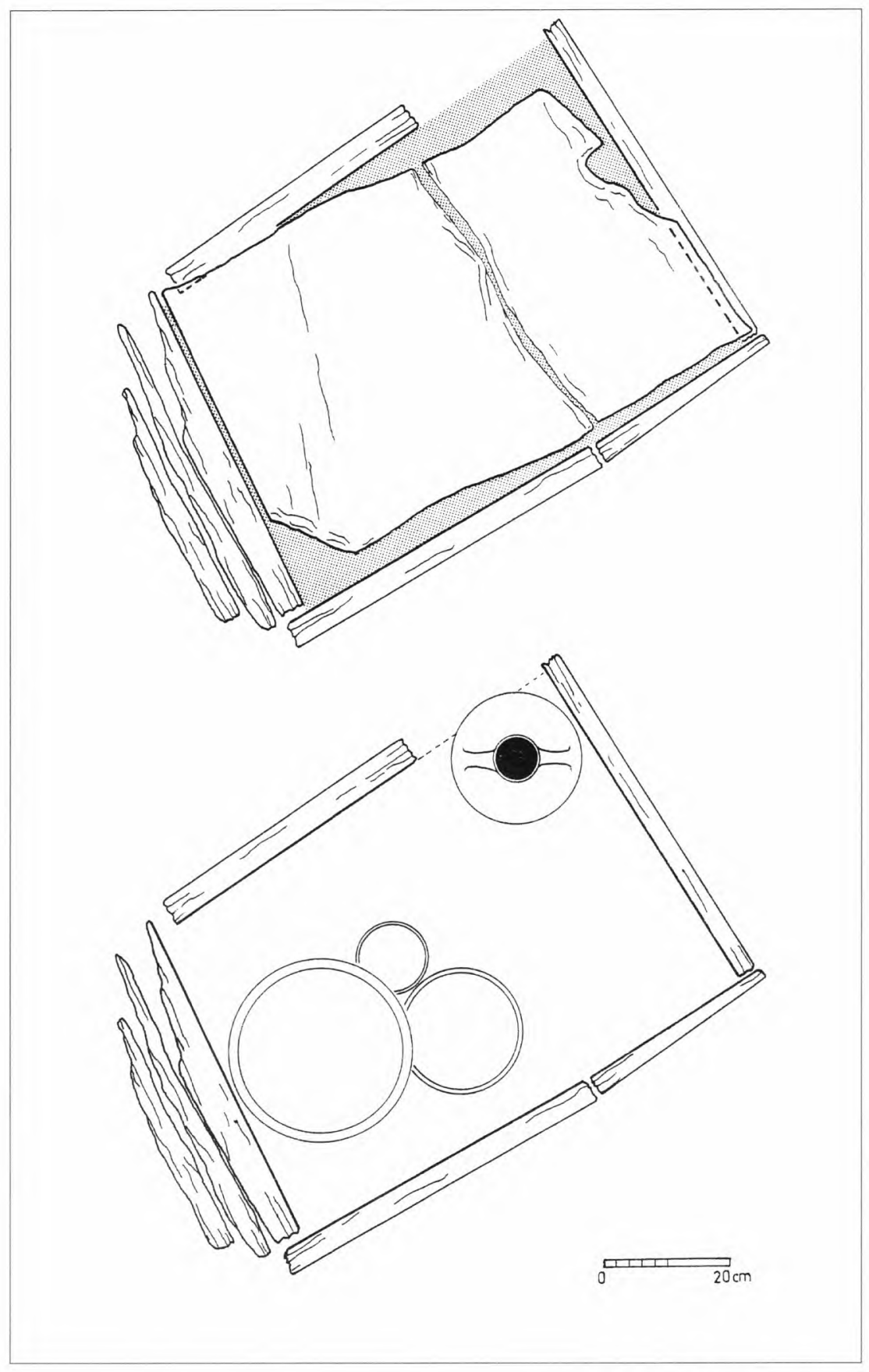

SEPULTURA 1 


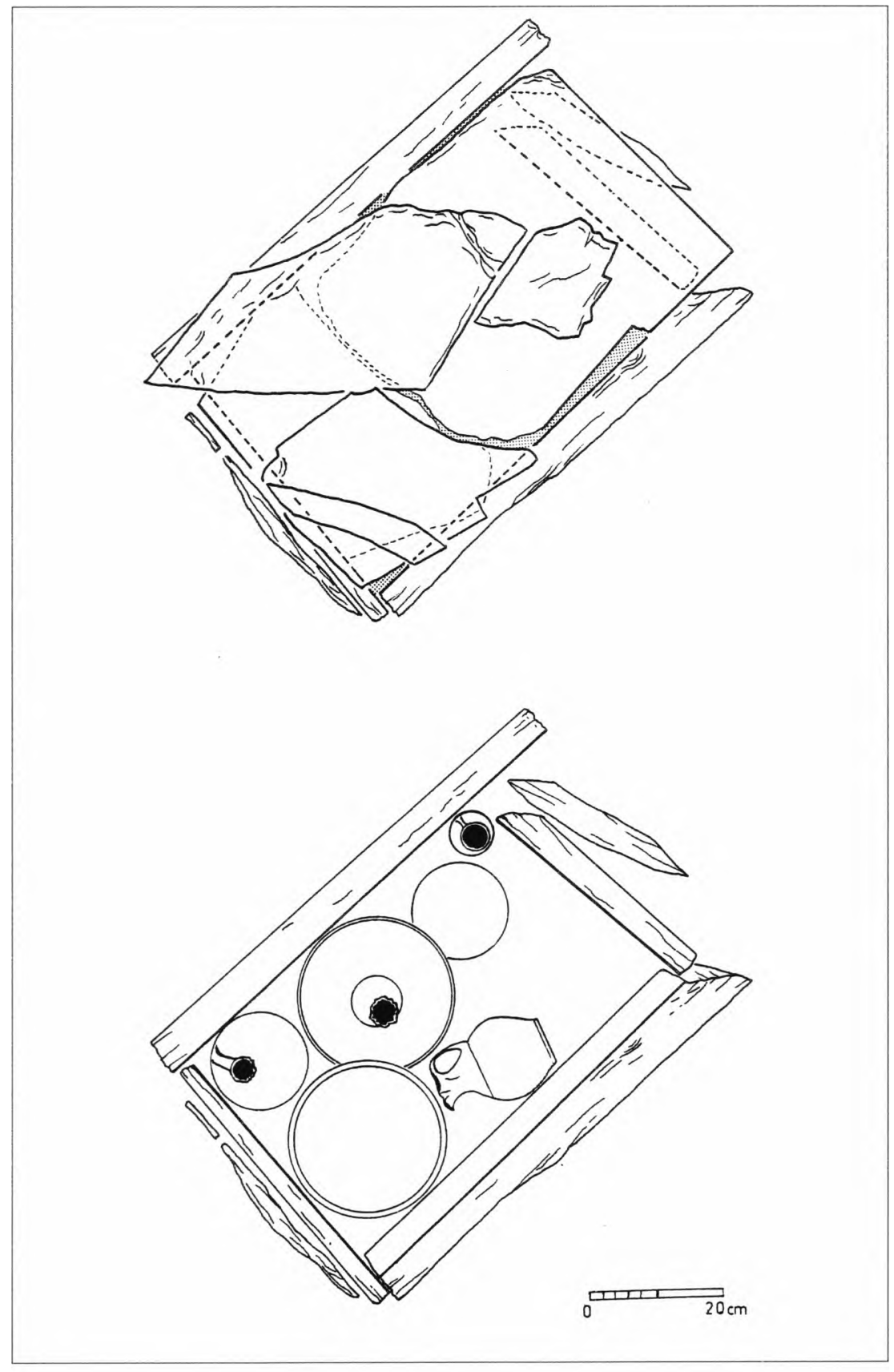

SEPULTURA 3 
EsT. IIC

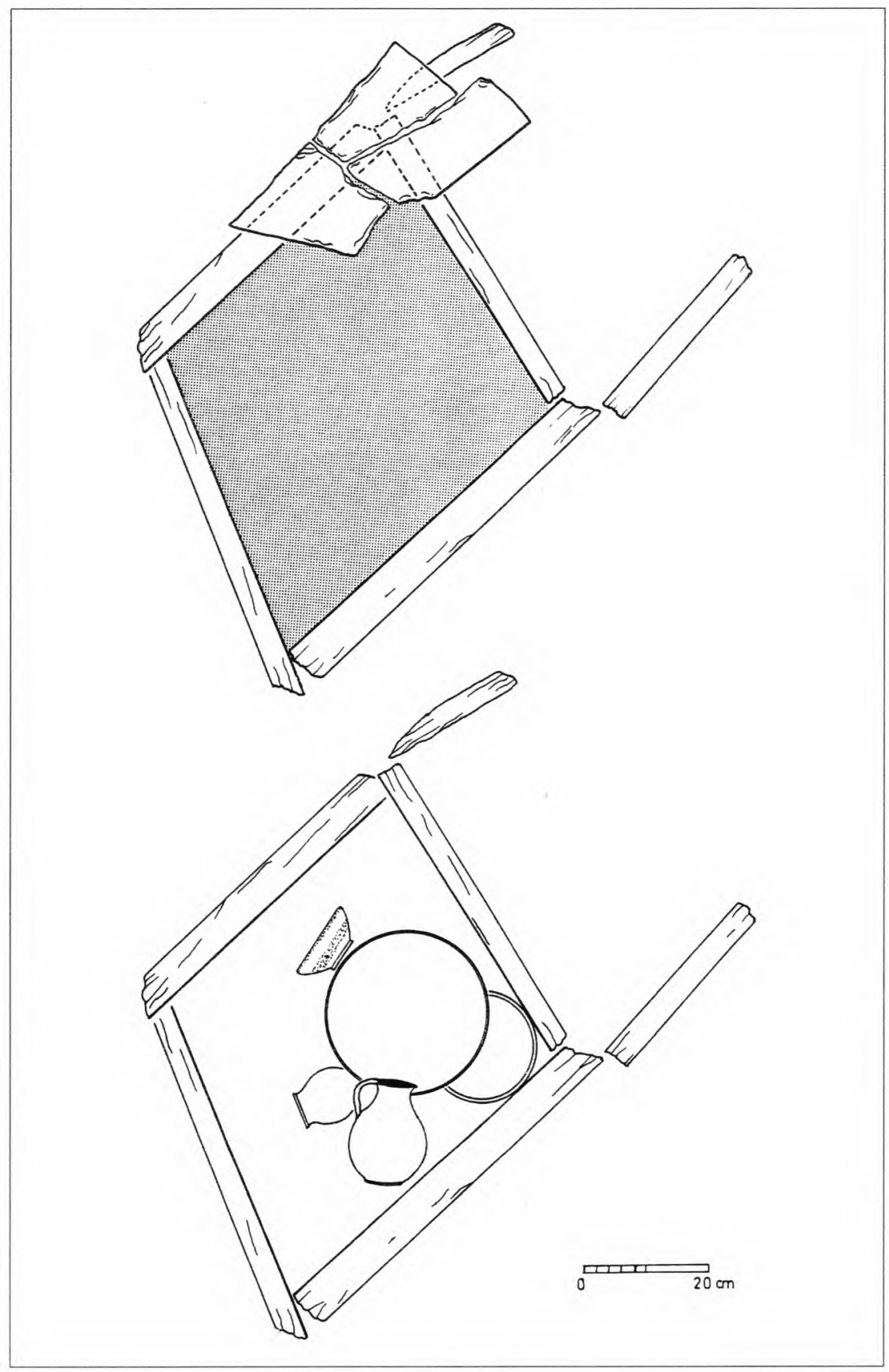

SEPULTURA 6 
EST. III

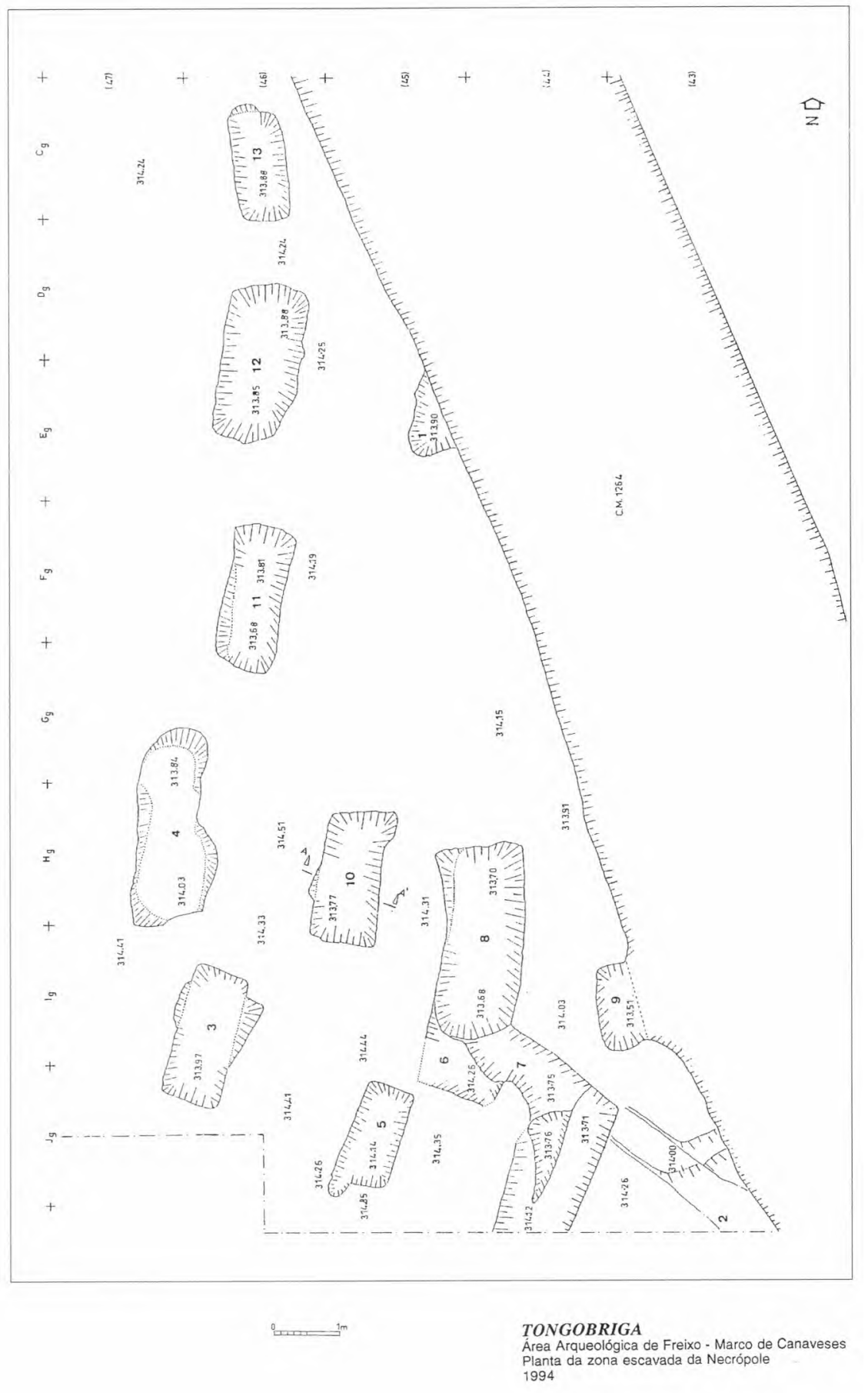



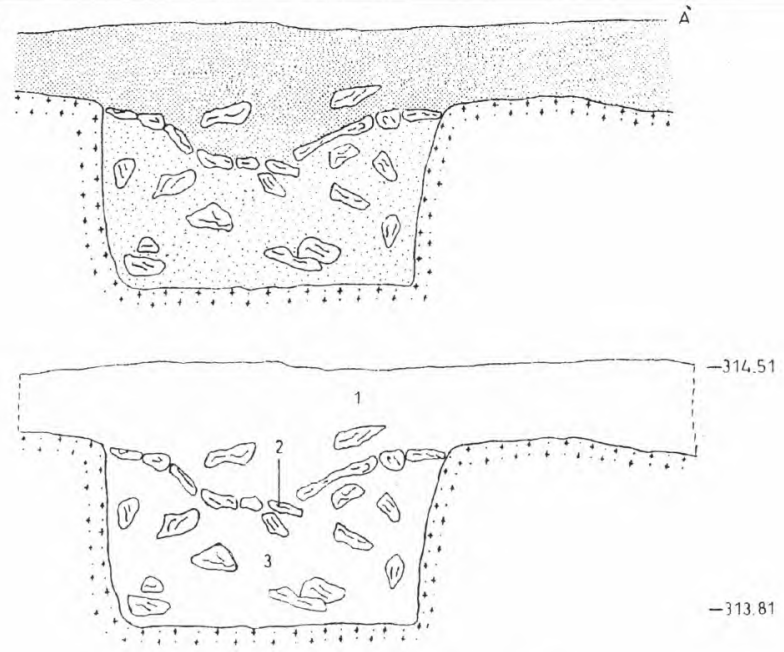

Sepultura 10 - Tongobriga

Estrato 1 - Superficial, camada com $0,30 \mathrm{~m}$ de espessura, que cobre todo 0 afloramento, Estrato 1 - Superficial, camada com 0,30m de espessura, que cober Estrato 2. Pedras que serviam de tampa a sepultura. Estrato 2 - Pedras que serviam de tampa a sepultura.

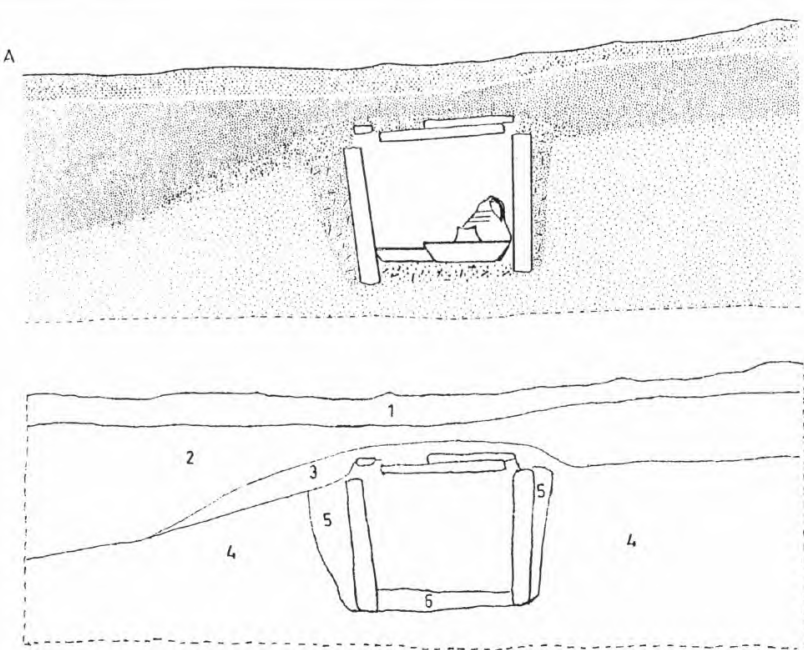

$-195.00$

\section{Sepultura 3 - Valbeirô}

0 $40 \mathrm{Cm}$

Estrato 1 - Terras superticiais com ralzame.

Estrato 2 . Terra negra, compacta, alectada por raizes, de escavação muito diflcl.

Estrato 3 - Terra escurecida, deilada sobre a sepultura, cobrindo-a totalmente.

strato 4 - Alloramento granitico afectado pela humidade.

strato 5 - O preenchimento das valas tol felto com terra conpactada. Embora a terra losse identica a da camada 2 , estava misturada com cinza.

Estrato 6 - O nivelamento do fundo de sepultura fol fello com terra, compactando-a 
EsT. V

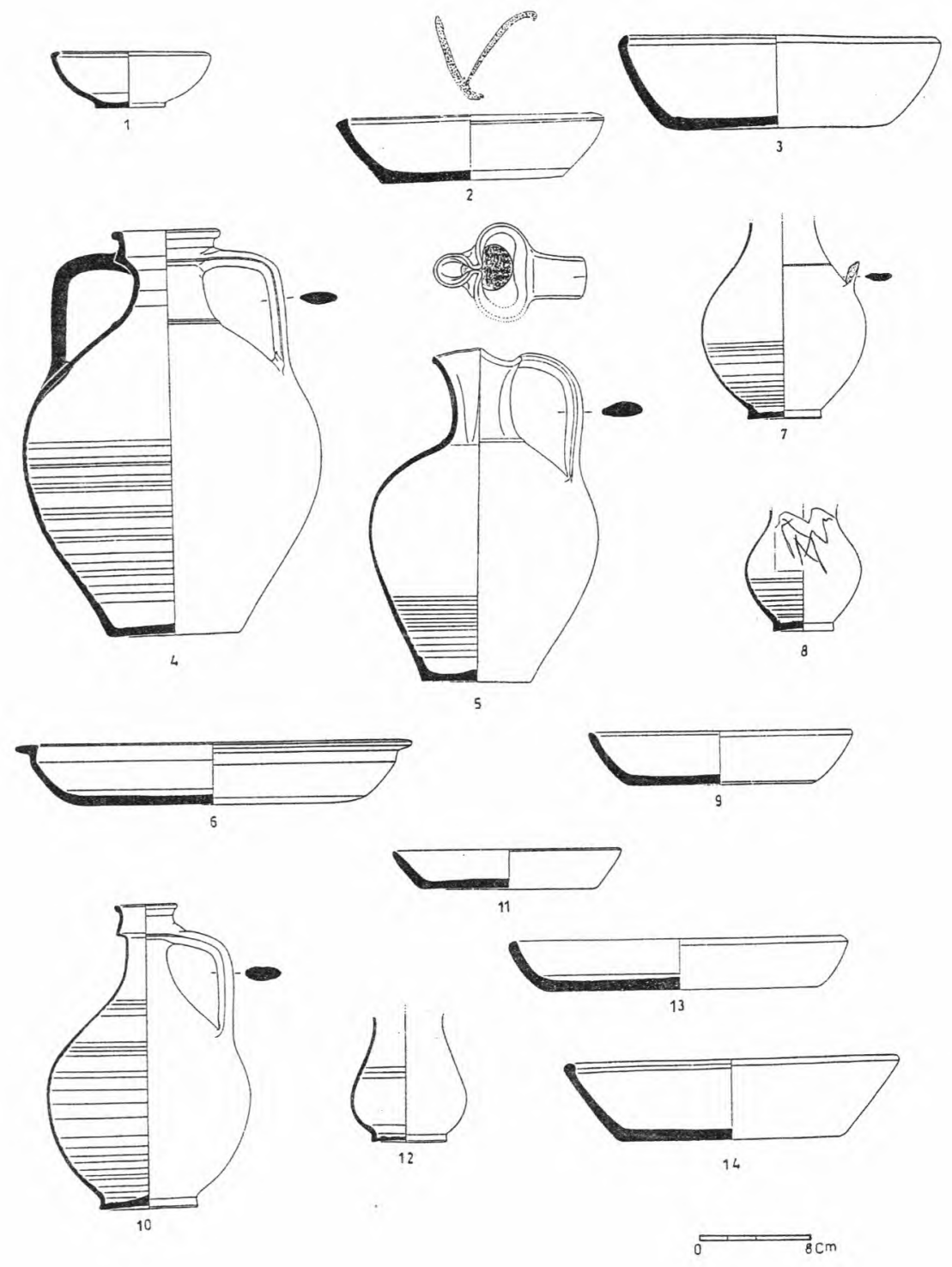


EST. VI

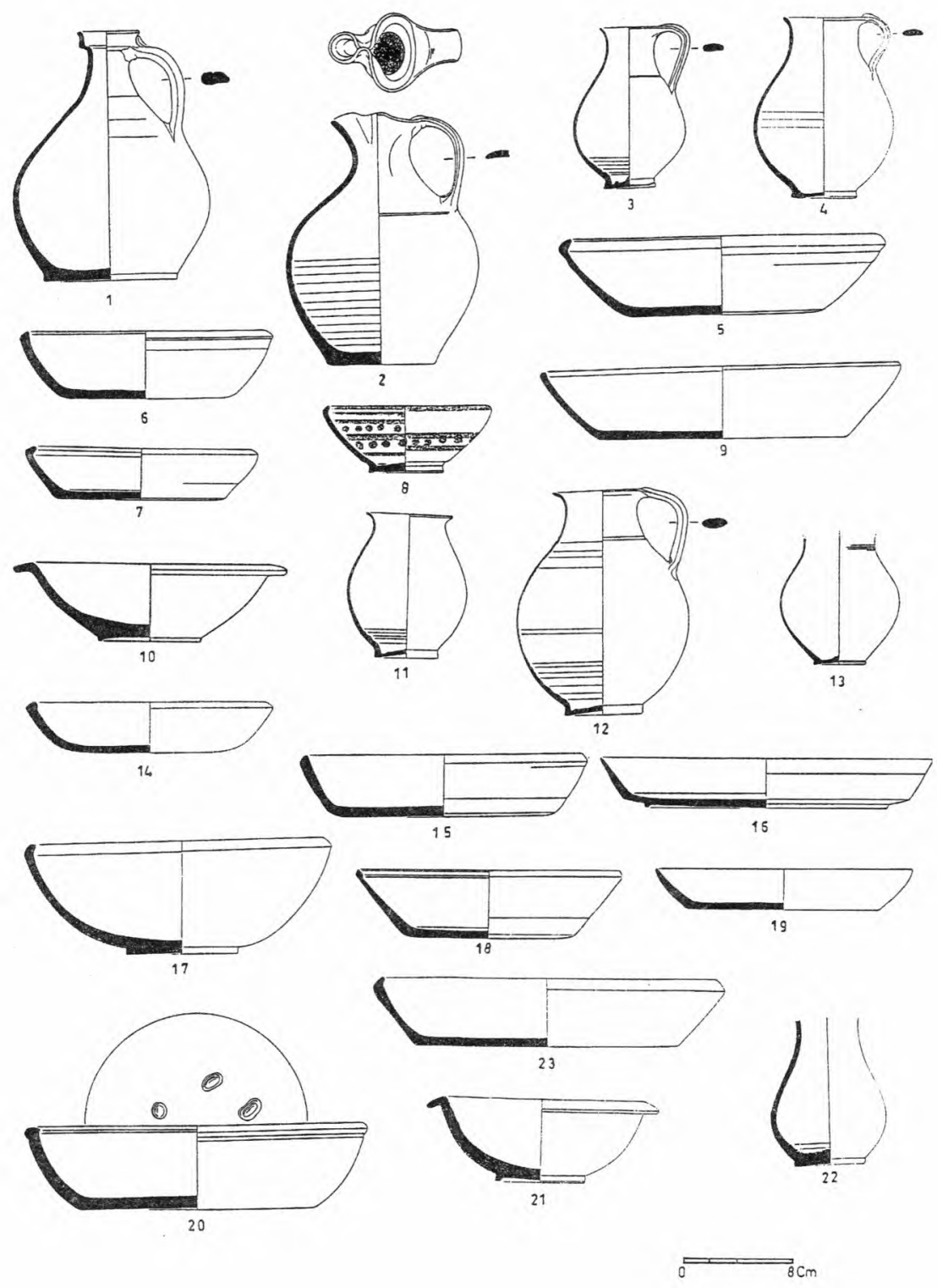


Est. VII
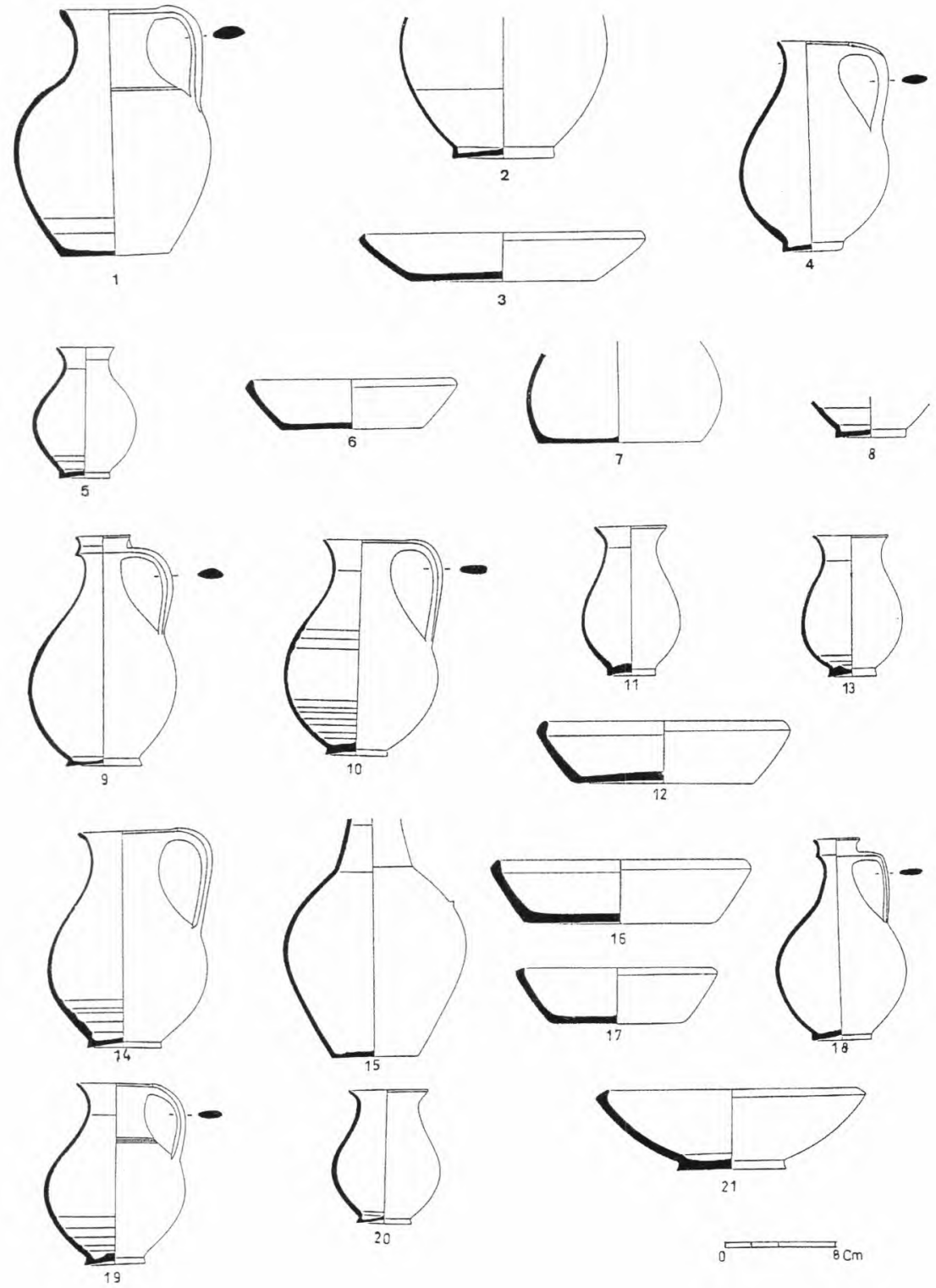

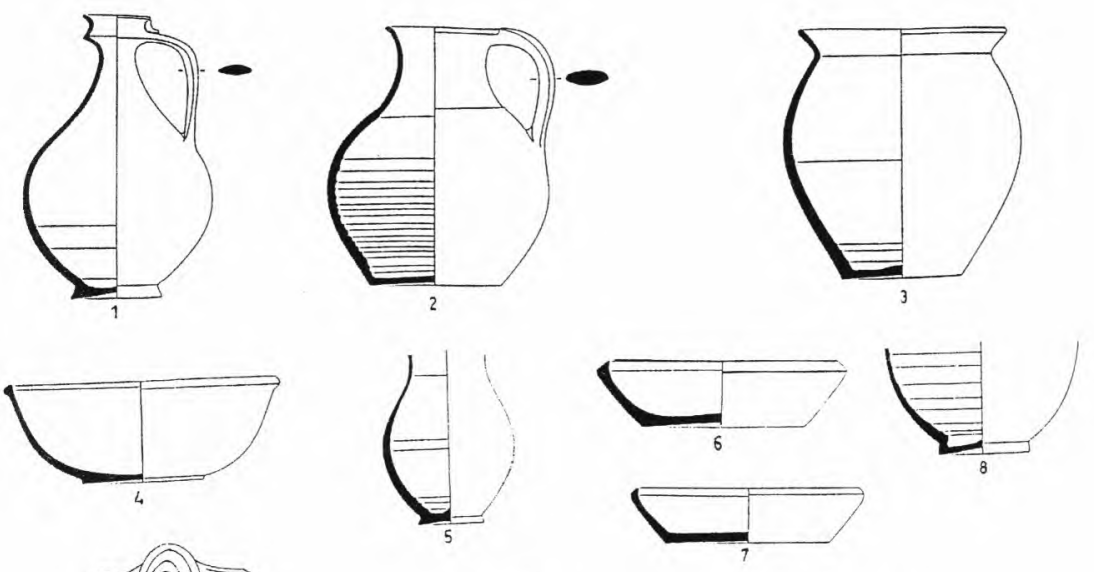

(1)
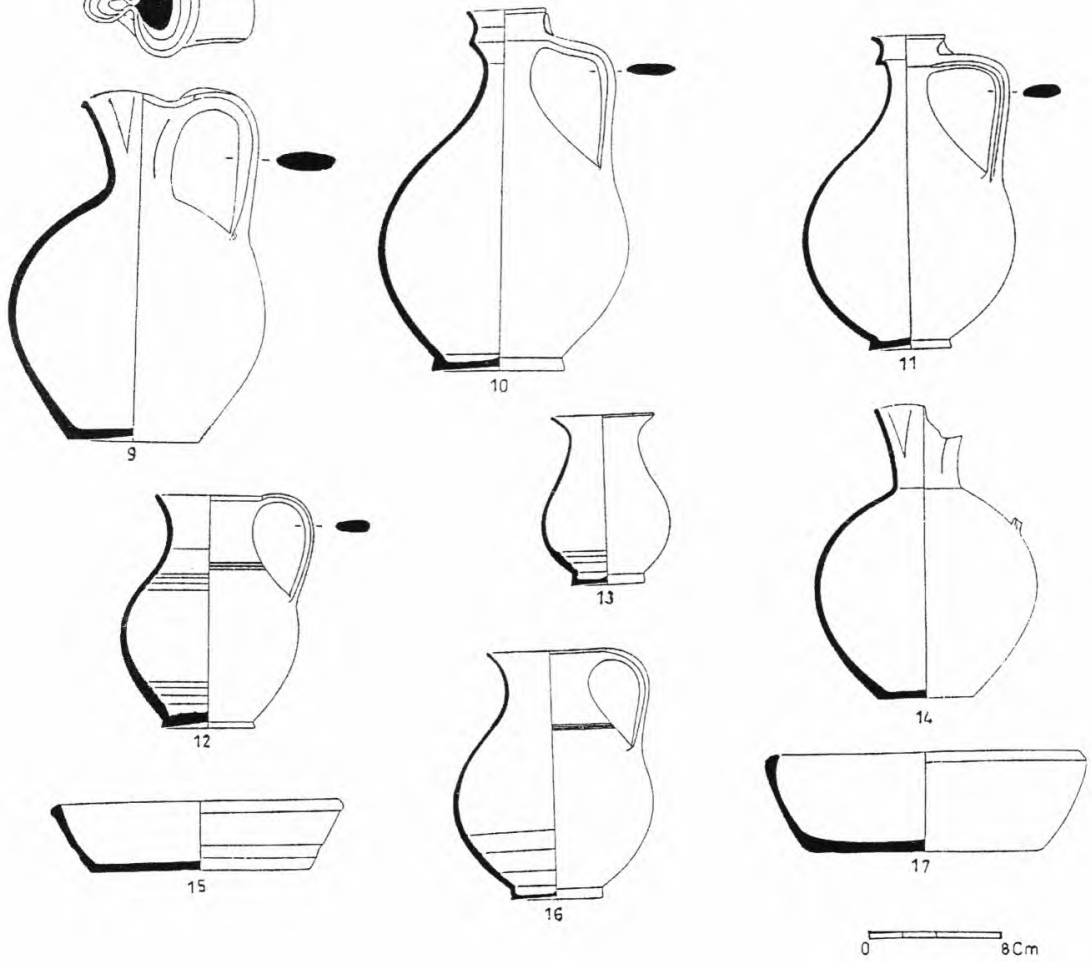
Est. IX
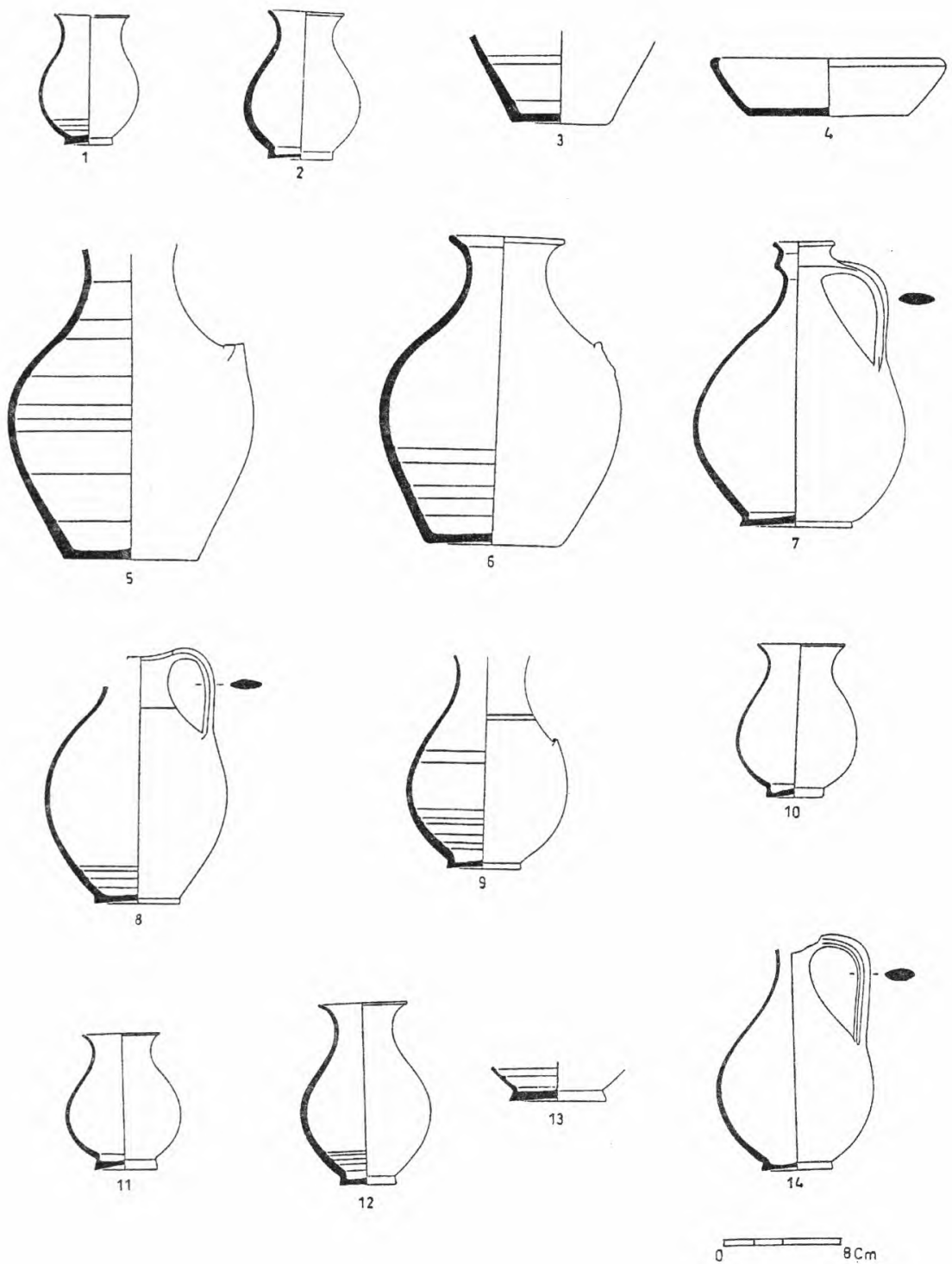

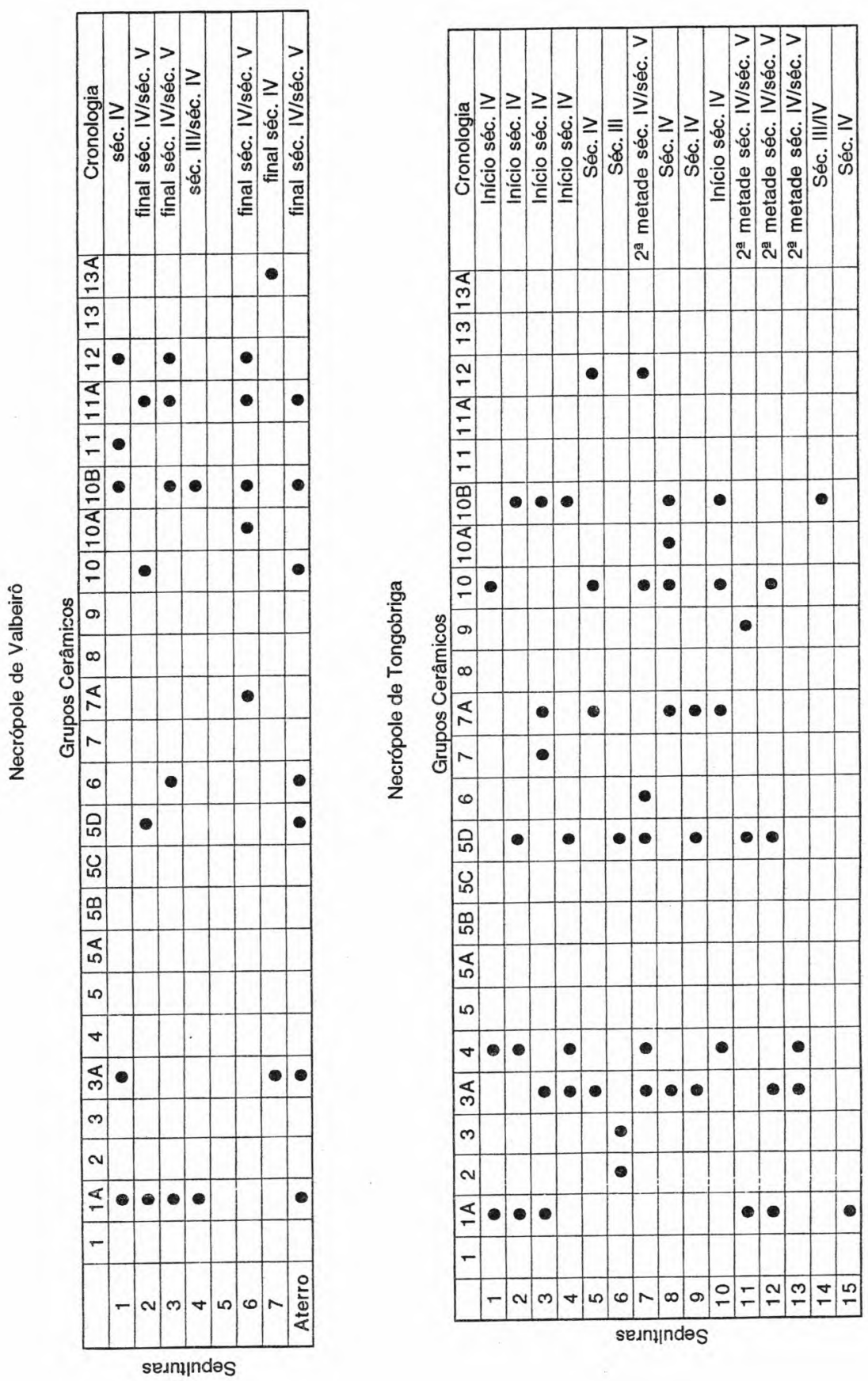


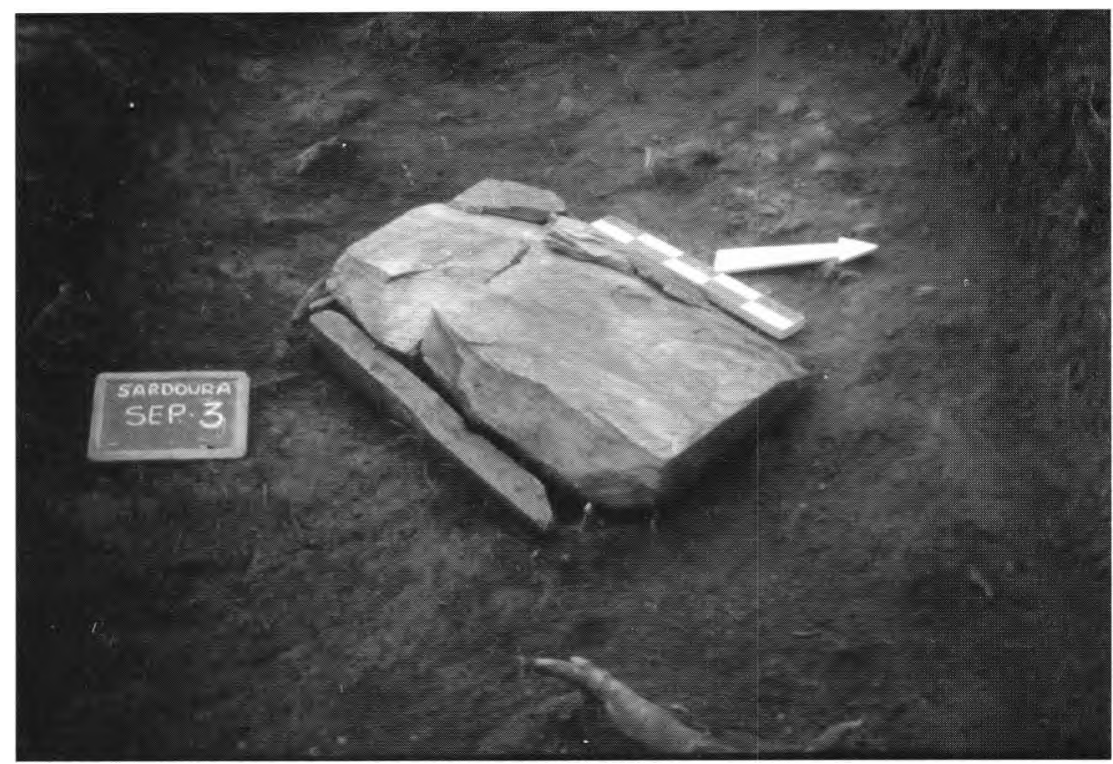

Valveirô - Sepultura 3, com tampa, antes da escavação do interior

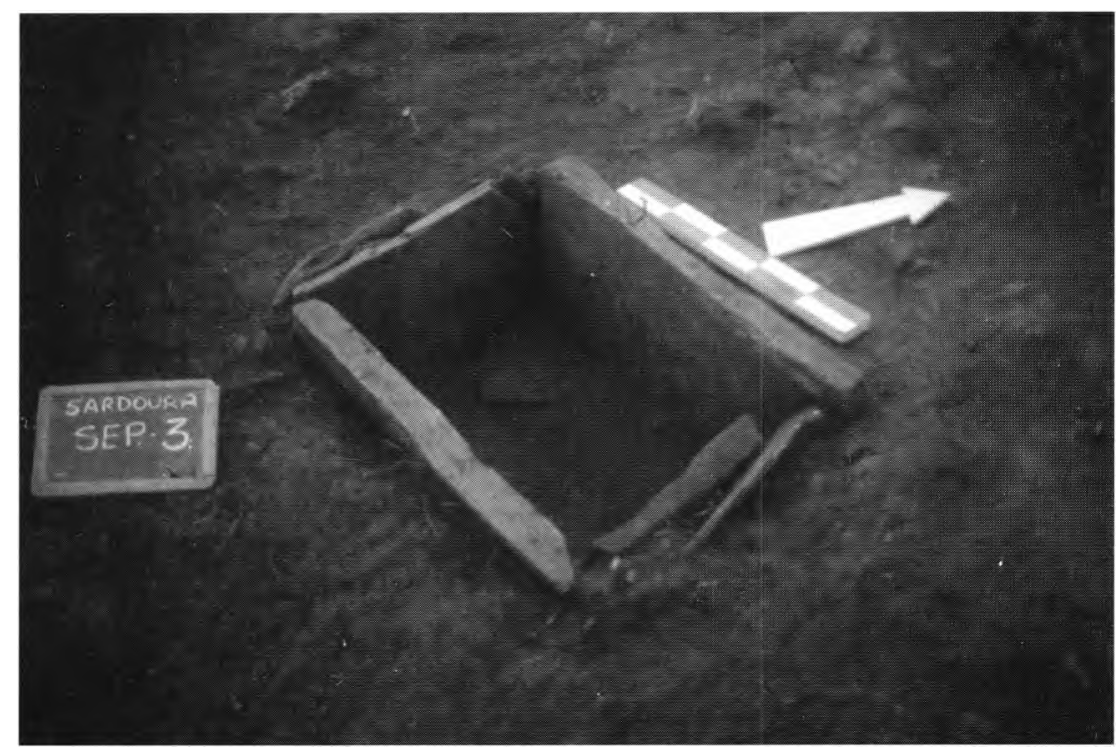

Valveirô - Sepultura 3, depois da escavação do interior 


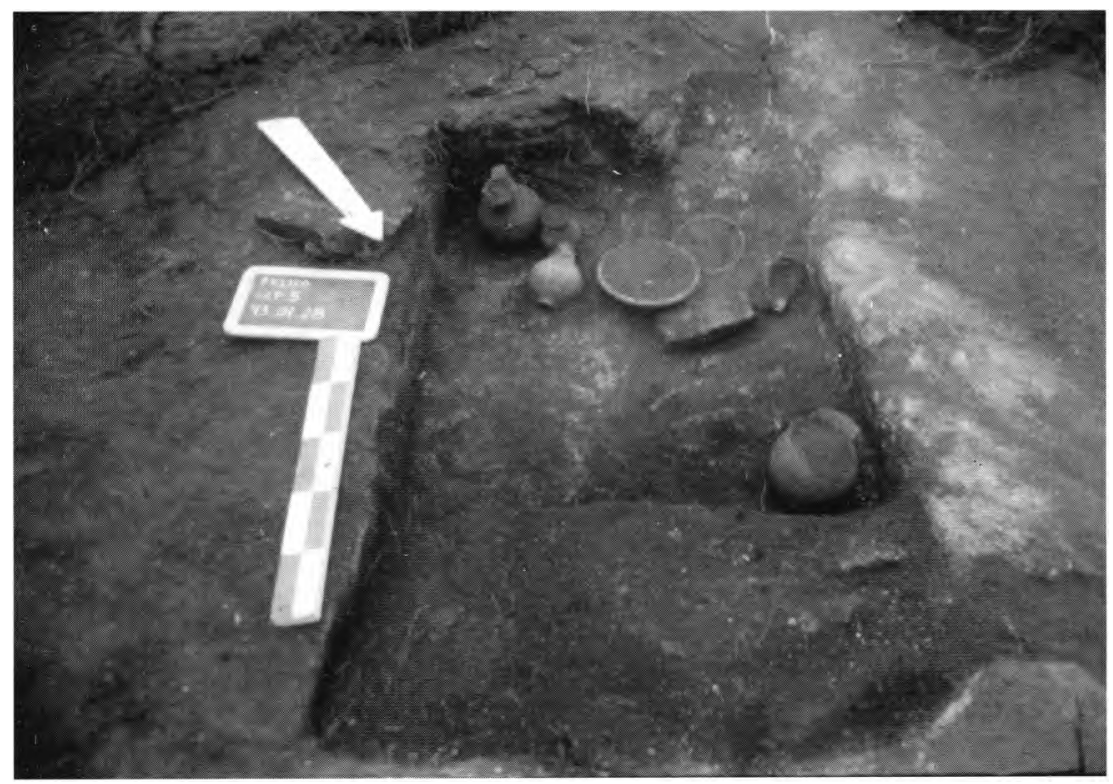

Tongobriga - Sepultura 5 aberta no afloramento granítico, em fase de escavação

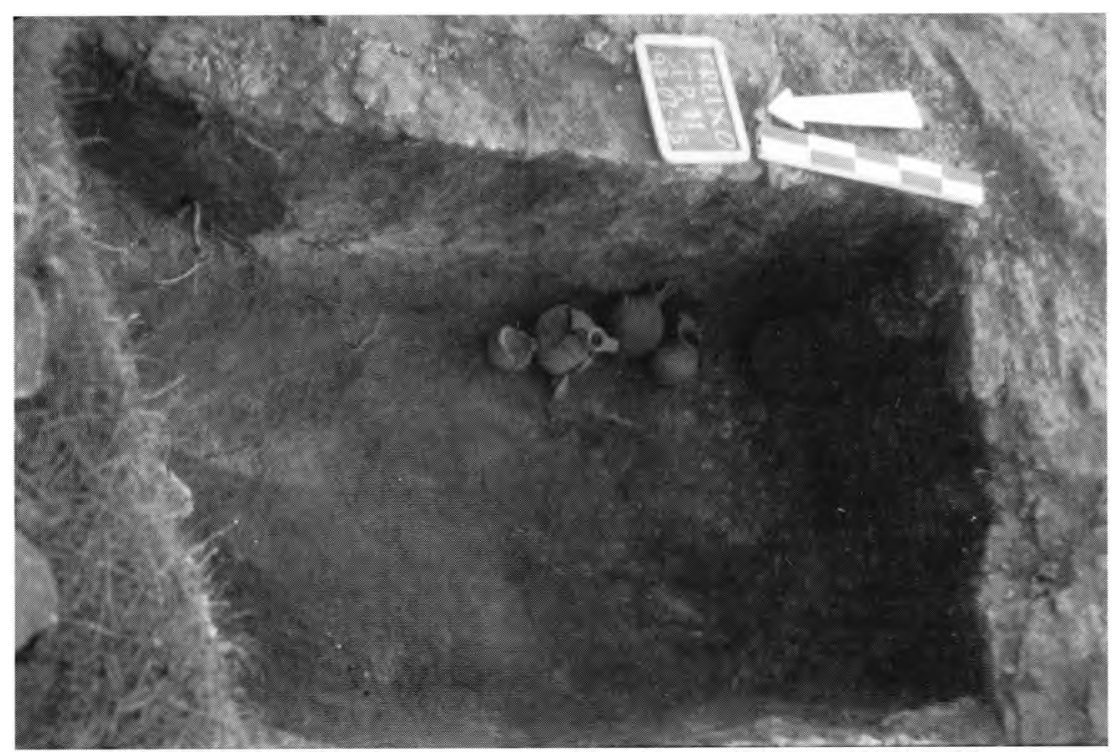

Tongobriga - Sepultura 11 aberta no afloramento granítico, depois de limpa das terras que a enchiam 